\title{
Geologic and anthropogenic sources of contamination in settled dust of a historic mining port city in northern Chile: health risk implications
}

Joseline S Tapia ${ }^{\text {Corresp.. }}{ }^{1}$ ， Jorge Valdés ${ }^{2,3}$ ， Rodrigo Orrego ${ }^{2}$ ， Andrei Tchernitchin ${ }^{4,5}$ ， Cristina Dorador ${ }^{6,7}$, Aliro Bolados ${ }^{5}$, Chris Harrod ${ }^{2,8}$

1 Instituto de Ciencias de la Tierra, Universidad Austral de Chile, Valdivia, Chile

2 Instituto de Ciencias Naturales Alexander von Humboldt, Universidad de Antofagasta, Antofagasta, Chile

3 Laboratorio de Sedimentología y Paleoambientes LASPAL, Universidad de Antofagasta, Antofagasta, Chile

4 Laboratorio de Endocrinología Experimental y Patología Ambiental ICBM, Facultad de Medicina, Universidad de Chile, Santiago, Chile

5 Departamento de Medio Ambiente, Colegio Médico de Chile, Santiago, Chile

6 Departamento de Biotecnología and Instituto Antofagasta, Universidad de Antofagasta, Antofagasta, Chile

7 Centre for Biotechnology and Bioengineering (CeBiB), Antofagasta, Chile

8 Núcleo Milenio INVASAL, Concepción, Chile

Corresponding Author: Joseline S Tapia

Email address: joseline.tapia@uach.cl

Chile is the leading producer of copper worldwide and its richest mineral deposits are found in the Antofagasta Region of northern Chile. Mining activities have significantly increased income and employment in the region, however there has been little assessment of the resulting environmental impacts to residents. The port of Antofagasta, located $1430 \mathrm{~km}$ north of Santiago, the capital of Chile, functioned as mineral stockpile until 1998 and has served as a copper concentrate stockpile since 2014. Samples were collected in 2014 and 2016 that show elevated concentrations of $\mathrm{As}, \mathrm{Cu}, \mathrm{Pb}$, and $\mathrm{Zn}$ in street dust and in residents' blood (Pb) and urine (As) samples. To interpret and analyze the spatial variability and likely sources of contamination, existent data of basement rocks and soil geochemistry in the city as well as public-domain airborne dust were studied. Additionally, a bioaccessibility assay of airborne dust was conducted and the chemical daily intake and hazard index were calculated to provide a preliminary health risk assessment in the vicinity of the port. The main conclusions indicate that the concentrations of $\mathrm{Ba}, \mathrm{Co}, \mathrm{Cr}, \mathrm{Mn}, \mathrm{Ni}$ and $\mathrm{V}$ recorded from Antofagasta dust likely originate from intrusive, volcanic, metamorphic rocks, dikes, or soil within the city. However, the elevated concentrations of $\mathrm{As}, \mathrm{Cd}, \mathrm{Cu}, \mathrm{Mo}, \mathrm{Pb}$, and $\mathrm{Zn}$ do not originate from these geologic outcrops, and are thus considered anthropogenic contaminants. The average concentrations of As, $\mathrm{Cu}$, and $\mathrm{Zn}$ are possibly the highest in recorded street dust worldwide at 239,10821 , and $11869 \mathrm{mgkg}^{-1}$, respectively. Furthermore, the contaminants $\mathrm{As}, \mathrm{Pb}$, and $\mathrm{Cu}$ exhibit the highest bioaccessibilities and preliminary health risk indices show that 
As and $\mathrm{Cu}$ contribute to elevated health risks in exposed children and adults chronically exposed to dust in Antofagasta, whereas $\mathrm{Pb}$ is considered harmful at any concentration. Therefore, an increased environmental awareness and greater protective measures are necessary in Antofagasta and possibly in other similar mining port cities in developing countries. 


\section{Title page}

2 Joseline Tapia ${ }^{1}$, Jorge Valdés ${ }^{2,3}$, Rodrigo Orrego ${ }^{2}$, Andrei Tchernitchin ${ }^{4,5}$, Cristina Dorador ${ }^{6,7}$,

3 Aliro Bolados 5 , and Chris Harrod 2,8

$4{ }^{1}$ Instituto de Ciencias de la Tierra, Facultad de Ciencias, Universidad Austral de Chile, Valdivia,

5 Chile.

6 Instituto de Ciencias Naturales Alexander von Humboldt, Universidad de Antofagasta, 7 Antofagasta, Chile.

8 32Laboratorio de Sedimentología y Paleoambientes LASPAL, Universidad de Antofagasta, 9 Antofagasta, Chile

$10{ }^{4}$ Laboratorio de Endocrinología Experimental y Patología Ambiental ICBM, Facultad de 11 Medicina, Universidad de Chile, Santiago, Chile.

$12{ }^{5}$ Departamento de Medio Ambiente, Colegio Médico de Chile, Santiago, Chile.

13 'Departamento de Biotecnología and Instituto Antofagasta, Universidad de Antofagasta, 14 Antofagasta, Chile.

$15{ }^{7}$ Centre for Biotechnology and Bioengineering (CeBiB), Antofagasta, Chile.

$16{ }^{8}$ Núcleo Milenio INVASAL, Concepción, Chile.

17 Corresponding author: Joseline Tapia ${ }^{1}$

18 Email address: joseline.tapia@uach.cl 
19 Geologic and anthropogenic sources of contamination in settled dust of a historic mining

20 port city in northern Chile: Health risk implications

\section{ABSTRACT}

22 Chile is the leading producer of copper worldwide and its richest mineral deposits are found in the Antofagasta Region of northern Chile. Mining activities have significantly increased income and employment in the region, however there has been little assessment of the resulting environmental impacts to residents. The port of Antofagasta, located $1430 \mathrm{~km}$ north of Santiago, the capital of Chile, functioned as mineral stockpile until 1998 and has served as a copper concentrate stockpile since 2014. Samples were collected in 2014 and 2016 that show elevated concentrations of $\mathrm{As}, \mathrm{Cu}, \mathrm{Pb}$, and $\mathrm{Zn}$ in street dust and in residents' blood $(\mathrm{Pb})$ and urine (As) samples.

To interpret and analyze the spatial variability and likely sources of contamination, existent data of basement rocks and soil geochemistry in the city as well as public-domain airborne dust were studied. Additionally, a bioaccessibility assay of airborne dust was conducted and the chemical daily intake and hazard index were calculated to provide a preliminary health risk assessment in the vicinity of the port. The main conclusions indicate that the concentrations of $\mathrm{Ba}, \mathrm{Co}, \mathrm{Cr}, \mathrm{Mn}$, $\mathrm{Ni}$ and $\mathrm{V}$ recorded from Antofagasta dust likely originate from intrusive, volcanic, metamorphic rocks, dikes, or soil within the city. However, the elevated concentrations of $\mathrm{As}, \mathrm{Cd}, \mathrm{Cu}, \mathrm{Mo}, \mathrm{Pb}$, and $\mathrm{Zn}$ do not originate from these geologic outcrops, and are thus considered anthropogenic contaminants. The average concentrations of $\mathrm{As}, \mathrm{Cu}$, and $\mathrm{Zn}$ are possibly the highest in recorded street dust worldwide at 239, 10821 , and $11869 \mathrm{mg} \cdot \mathrm{kg}^{-1}$, respectively. Furthermore, the contaminants $\mathrm{As}, \mathrm{Pb}$, and $\mathrm{Cu}$ exhibit the highest bioaccessibilities and preliminary health risk indices show that $\mathrm{As}$ and $\mathrm{Cu}$ contribute to elevated health risks in exposed children and adults 
42 chronically exposed to dust in Antofagasta, whereas $\mathrm{Pb}$ is considered harmful at any

43 concentration. Therefore, an increased environmental awareness and greater protective measures

44 are necessary in Antofagasta and possibly in other similar mining port cities in developing

45 countries.

\section{I INTRODUCTION}

47 The process of economic development often results in large-scale anthropogenic impacts to the 48 environment and inhabitants of developing countries. Previous well-reported examples of

49 environmental pollution caused by industrial activities include: (i) the 1984 Bhopal incident in

50 India after more than 40 tons of methyl isocyanate gas leaked from a pesticide plant (Broughton,

51 2005), (ii) Chernobyl, Ukraine, in 1986, after the nuclear energy plant explosion of Reactor 4

52 (Devell et al., 1986; Gale, 1987), (iii) the Baia Mare spill, Romania, in 2000, where nearly

$53100000 \mathrm{~m}^{3}$ of cyanide and metal-rich liquid waste was released into the river system near this

54 city (Lucas, 2001; Soldán et al., 2001), and (iv) Sukinda, India, where the most harmful form of 55 chromium $(\mathrm{Cr}[\mathrm{VI}])$ pollutes water and inhabitants due to mining activities (Dubey, Sahoo \&

56 Nayak, 2001). As such, industrial incidents have been related to severe health issues and

57 fatalities (Khan \& Abbasi, 1999).

58 Despite harmful consequences that industry and uncontrolled anthropogenic activities have 59 caused and are still contributing to (Reddy \& Yarrakula, 2016), an awareness of the 60 environmental impact of these activities is growing in many developing countries. Chile, a 61 developing country located along the western border of southern South America, is one example 62 where an environmental awareness has increased with time on a national scale. Among its 63 developing characteristics is the fact that the country predominantly relies on the exploration, 64 exploitation, and exportation of mineral resources as one of its main economic activities (De 
65 Solminihac, Gonzales \& Cerda, 2017). Although often associated with environmental

66 degradation, these activities support an elevated gross domestic product (GDP) that has allowed

67 Chile to be included in the Organization for Economic Co-operation and Development (OECD;

68 Ruiz-Rudolph et al., 2016).

\subsection{Antofagasta Region background}

70 Copper $(\mathrm{Cu})$ is the most significant metallic resource of Chile: the country has contributed approximately $28 \%$ of the world's Cu production since 1985 (COCHILCO, 2014). This element is naturally distributed in northern Chile, principally in the Antofagasta Region (Fig. 1a; Aroca, 2001), where large-to-giant porphyry copper deposits are found (e.g. Chuquicamata, La Escondida, and Radomiro Tomic, among others; Fig. 1b). As such, numerous large-scale mining operations and mineral deposits in the Antofagasta Region have supported the economic development of the region to the point where the per capita GDP is the highest in the country.

Following the War of the Pacific (1879 to 1884), Chile and Bolivia signed a trade agreement in 1904 which allowed Bolivian products to be exported from the Train Station and Port of Antofagasta, where resultantly, unprotected stockpiles containing metals (mainly $\mathrm{Pb}$ ) became common at those facilities (Sepúlveda, Vega \& Delgado, 2000).

81 It is also important to consider other natural and anthropogenic sources of contamination in

82 Antofagasta that accompanied heightened mining and a related increase in population (by a 83 factor of nearly 6.5 between 1895 (13530 inhabitants; Censo, 1895) and 1960 (87860

84 inhabitants; Censo, 1960)): (i) of the sparse fresh water sources in the region, the Toconce and 85 Holajar rivers were naturally enriched in As, resulting in chronic contamination of drinking water until 1970 (Marshall et al., 2007), and (ii) in the late 1970s, La Negra Industrial Complex

87 was established $20 \mathrm{~km}$ southeast of Antofagasta which included cement production (Industria 
88 Nacional de Cemento SA; Inacesa), lithium (Li) processing (Sociedad Chilena del Litio and

89 SQM), and a smelter (Refimet, currently Altonorte of Xstrata Copper; Minería Chilena, 2013).

90 At the end of $1980 \mathrm{~s}$, elevated $\mathrm{Pb}$ levels in blood were reported in children attending schools and

91 living close to the Antofagasta Port and Antofagasta Train Station facilities (Sepúlveda, Vega \&

92 Delgado, 2000; Tchernitchin et al., 2006). As a result, in the early 1990s, the stockpiles of Pb-

93 rich materials originating from Bolivia were transferred to Portezuelo, $18 \mathrm{~km}$ southeast of

94 downtown Antofagasta, in close proximity to La Negra Industrial Complex. Protective measures

95 related to the transport and deposition of concentrate from Portezuelo to Antofagasta Port were

96 not known to be established prior to 2010 (MTT, 2015).

97 Combined lung and bladder cancer mortality rates in the Antofagasta Region were the highest

98 reported for the whole country between 1992 and 1994 (153 and 50 per 100000 men and women,

99 respectively), attributable to the chronic ingestion of As between 1958 and 1970 (Marshall et al.,

100 2007). In 2014, despite documented adverse health impacts to the population of Antofagasta and

101 relocation of the Bolivian stockpiles, the development of $\mathrm{Cu}, \mathrm{Mo}$, and $\mathrm{Ag}$ exploitation in the

102 Sierra Gorda district, $140 \mathrm{~km}$ northeast of the city of Antofagasta (Fig. 1b; Minería Chilena,

103 2014), led to the construction of a holding facility inside the Antofagasta Port called the galpón

104 (warehouse), located close to the center of the city, which currently stores Chilean $\mathrm{Cu}$

105 concentrate. Aside from $\mathrm{Cu}$ (nearly 32\%), the concentrate contains other elements such as $\mathrm{S}, \mathrm{Fe}$,

$106 \mathrm{Zn}, \mathrm{As}, \mathrm{Pb}, \mathrm{Mo}, \mathrm{Sb}$, and Cd (Table 1 in Fuentes, Viñals \& Herreros, 2009). As port operations

107 continued, local inhabitants noticed the increase of dust on buildings etc., which led to criticism

108 of the operations associated with the galpón and the port. Resultantly, social organizations were

109 established, such as Este polvo te mata ("This dust kills you"), leading to ongoing environmental

110 conflicts within the city. 
111 Currently, the city of Antofagasta has 361873 inhabitants (INE, 2017), which is nearly 4 times

112 greater than the 1960 population (Censo, 1960). The city has grown and developed around the

113 port (Fig. 1c); as a result, $5.7 \%$ of the national state load and $17.3 \%$ of all regional transport

114 passes through the port (MTT, 2015). Important locations situated near the Antofagasta Port

115 include the downtown area of Antofagasta, hospitals, schools, preschools, the municipal square,

116 the city shopping mall, and commercial centers (Fig. 1c).

$117 \quad 1.2$ Previous sampling campaigns

118 Due to increased social pressure associated with the Antofagasta dust, in 2014, the Chilean State

119 sampled city dust and human blood and urine from locations in close proximity to, and up to 9

$120 \mathrm{~km}$ distance from the Antofagasta Port (Table 1). Contaminant concentrations were quantified in

121 the $<63 \mu \mathrm{m}$ size fraction by the Chilean Public Health Institute (ISP-Instituto de Salud Pública;

122 ISP, 2014). Elevated levels of $\mathrm{Pb}$ in blood and of As in urine were found in children attending

123 preschools close to the Antofagasta Port, and elevated concentrations of a number of elements

124 were also reported in street dust, including $\mathrm{As}, \mathrm{Cu}, \mathrm{Pb}$, and $\mathrm{Zn}$ (Vergara, 2015). More recently,

125 the Chilean College of Physicians (CM-Colegio Médico) undertook another sampling campaign

126 in 2016 to compare concentrations with the values from 2014 for determining which

127 contaminants were still present in the $<63 \mu \mathrm{m}$ size fraction of dust (Tchernitchin \& Bolados,

128 2016). Details regarding the methodologies used in these previous studies are found in Table 2.

\section{$129 \quad 1.3$ Study objectives}

130 Despite the recent 2014 and 2016 sampling events, no analyses were conducted to evaluate and

131 understand the spatial distribution, variation, and sources associated with health risks by

132 exposure to these metallic and metalloid (As) contaminants apart from their bioaccessibility.

133 Also, regardless of well-reported improvements in the technology used to transport and store 
134 material inside the Antofagasta Port (MTT, 2015), currently there is little evidence that the

135 environmental issues and negative health impacts on Antofagasta residents have improved, and

136 regulations have not been put into effect to control the contamination. Therefore, considering the

137 need to better understand and establish (i) the spatial-temporal variability of the present

138 contaminants, (ii) the likely source of contamination through the comparison of natural

139 background concentrations, (iii) human health risk standards associated with exposure to the dust

140 from the Antofagasta Port, and (iv) the bioaccessibility of the contaminant elements, a health risk

141 assessment and bioaccessibility assay were conducted, and raw data collected in 2014 (ISP,

142 2014) and 2016 (Tchernitchin \& Bolados, 2016) was further interpreted and analyzed to improve

143 the understanding of pollution in Antofagasta and better inform regulators and interested parties

144 in the support of new environmental policies and regulations.

\section{2 METHODOLOGY}

\section{$146 \quad 2.1$ Data compilation}

147 Information related to the elemental concentrations of metals was compiled from previous

148 studies of (i) street dust and (ii) the composition of geologic outcrops, weathered products, and

149 soil in the area of Antofagasta.

\section{$150 \quad$ 2.1.1 Antofagasta street dust}

151 Starting 1993, leaded fuels were banned by law in Santiago, Chile (Faiz, Weaver \& Walsh, 152 1996), as well as in other regions of the country thereafter. In medium- to low-size coastal cities 153 of Chile, such as Tocopilla, located at $175 \mathrm{~km}$ north of Antofagasta, it has been shown that 154 vehicle emissions do not significantly contribute to ambient particulate matter concentrations in 155 the city (Jorquera, 2009). Therefore, street dust in urban areas of Antofagasta is considered to be 156 an indicator of metal and metalloid contamination from atmospheric deposition, and public dust 
157 samples from a number of key city locations were compiled from ISP (ISP, 2014) and CM

158 (Tchernitchin \& Bolados, 2016) (Tables 1 and 2). These sampling data are simply reported from

159 those sources and reinterpreted in the context of other factors such as the background geology,

160 which depending on the host rock mineral composition, can weather and contribute to increased

161 concentrations of the same contaminant elements.

\section{$162 \quad$ 2.1.2 Geologic outcrops, weathered products, and soil}

163 The main geologic formations of Antofagasta correspond to Jurassic volcanic basic to 164 intermediate rocks of the La Negra Formation and Neogene marine sedimentary rocks of La 165 Portada Formation, constituted by sandstones and coquinas, of which the latter is a form of 166 limestone represented by an agglomerate of shells (SERNAGEOMIN, 2003). Concentrations of $167 \mathrm{As}, \mathrm{Ba}, \mathrm{Cd}, \mathrm{Co}, \mathrm{Cr}, \mathrm{Cu}, \mathrm{Fe}, \mathrm{Mn}, \mathrm{Mo}, \mathrm{Ni}, \mathrm{Pb}, \mathrm{V}$, and $\mathrm{Zn}$ of volcanic, intrusive, metamorphic 168 rocks, and dikes of Antofagasta were compiled from Lucassen \& Franz (1994), Oliveros et al. 169 (2007), and Rogers \& Hawkesworth (1989) (Fig. 2a). In addition, unpublished data (As and Mo) 170 of Oliveros et al. (2007) was utilized. Element concentrations from sedimentary rocks of the La

171 Portada Formation were not available, however the composition of soil, an exogenous matrix

172 associated with the weathering of parent rocks, was obtained from De Gregori et al. (2003; 2 173 soils around Antofagasta city) and CENMA (2014; 15 background samples and 2 contaminated 174 samples from Antofagasta). A brief summary of the methodologies used in these studies is 175 presented in Table 2.

\section{$176 \quad 2.2$ Data analysis}

\section{2.2.1 Spatial distribution of the geologic outcrops and dust samples}

178 The spatial distribution of regional volcanic, intrusive, metamorphic rocks, dikes, and soils was 179 plotted using the Geographic Information System QGIS (2.6.1 Brighton) software (Fig. 2a). 
180 Local-scale surficial geology (1:50000), provided by the program Geología para el

181 Ordenamiento Territorial de Antofagasta of the National Service of Geology and Mining

182 (Servicio Nacional de Geología y Minería SERNAGEOMIN, 2014), was used to plot the

183 distribution of Antofagasta dust samples and their corresponding relationship to the geologic

184 outcrops (Fig. 2b).

\section{$185 \quad$ 2.2.2 Metal and metalloid statistics}

186 To determine basic characteristics of the $\mathrm{As}, \mathrm{Ba}, \mathrm{Cd}, \mathrm{Cr}, \mathrm{Cu}, \mathrm{Mn}, \mathrm{Mo}, \mathrm{Ni}, \mathrm{Pb}, \mathrm{V}$, and $\mathrm{Zn}$ data,

187 univariate statistics (e.g. mean, standard deviation, median, minimum, maximum, lower and

188 upper limit of confidence interval (95\%)) were calculated in SYSTAT (2009). Principal

189 component analysis (PCA) was conducted on $\log _{\mathrm{e}}(\mathrm{x}+1)$-transformed, normalized data in

190 PRIMER 7 (Clarke \& Gorley, 2006). In addition, comparisons to the upper continental crust

191 (UCC; from Rudnick \& Gao, 2003) are also presented.

\section{$192 \quad$ 2.2.3 Geo-accumulation index and enrichment factor}

193 To infer contaminant elements and sources of street dust, numerous studies have utilized the

194 geoaccumulation index ( $\mathrm{I}_{\text {geo }}$; Equation 1; e.g., Lu et al., 2009; Li et al., 2013) and enrichment

195 factor (EF; Equation 2; e.g., Zoller, Gladney \& Duce, 1974; Lu et al., 2009), respectively.

$196 \quad I_{g e o}=\log _{2}\left(\frac{C_{n}}{1.5 \times B_{n}}\right)$

197 In Equation 1, $C_{n}$ corresponds to the measured concentration of metal $n$ in the sediment and $B_{n}$ is

198 the local background value of the metal $n$. A factor of 1.5 was used for possible variations of the

199 local background due to variable lithologies (Muller, 1979; Nowrouzi \& Pourkhabbaz, 2014).

200 The local background value $\left(B_{n}\right)$ of each metal was obtained from volcanic, intrusive,

201 metamorphic rocks, dikes, and soils in the region. Specific values of the $\mathrm{I}_{\text {geo }}$ index indicate the 202 following: 
$203 \mathrm{I}_{\mathrm{geo}} \leq 0$, the sample is not contaminated;

$2040<\mathrm{I}_{\text {geo }} \leq 1$, the sample is non- to slightly contaminated;

$2051<\mathrm{I}_{\text {geo }} \leq 2$, the sample is moderately contaminated;

$2062<\mathrm{I}_{\mathrm{geo}} \leq 3$, the sample is moderately to highly contaminated;

$2073<\mathrm{I}_{\mathrm{geo}} \leq 4$, the sample is highly contaminated;

$2084<\mathrm{I}_{\text {geo }} \leq 5$, the sample is highly to extremely contaminated;

$209 \mathrm{I}_{\mathrm{geo}}>5$, the sample is extremely contaminated.

210 Enrichment Factors (EFs; Equation 2) were calculated using the geochemical composition of

211 basement rocks and soil of Antofagasta, with $\mathrm{Fe}$ as the normalizing element.

$212 E F=\frac{M_{1}}{E_{\text {ref } 1}} / \frac{M_{2}}{E_{\text {ref } 2}}$

213 In Equation 2, EF is equivalent to the Enrichment Factor (Zoller, Gladney \& Duce, 1974). $M_{l}$ is

214 the metal or metalloid concentration in the sample, $E_{\text {ref } l}$ is the reference element in the sample

$215(\mathrm{Fe}), M_{2}$ is the background concentration of the metal or metalloid, and $E_{\text {ref } 2}$ is the background

216 concentration of the reference element (Fe in intrusive, volcanic, metamorphic rocks, dikes, and

217 soil of Antofagasta). Fe, Al, or Ti have been used as reference elements in previous studies

218 (Rule, 1986; Ergin et al., 1991; Tapia et al., 2012), however Fe was chosen as the reference

219 element here because it was the only conservative element present in all of the utilized data sets.

$220 \quad 2.3$ Health risk assessment

221 To obtain a preliminary health risk assessment associated with exposure to Antofagasta dust, the

222 chemical daily intake (CDI; Equation 3) of the studied elements was calculated by ingestion

223 exposure while considering the start of the galpón and chronic exposure as 2 and 70 years,

224 respectively. Dust consumption and body weight were obtained from the US EPA (1989).

$225 C D I_{\text {ingestion }}=\frac{C \times \operatorname{Ing} R \times E_{\text {freq }} \times E_{\text {dur }}}{B W \times A T}$ 
226 In Equation 3, $C D I_{\text {ingestion }}$ corresponds to the chemical daily intake (in $\mathrm{mg} \cdot \mathrm{kg}^{-1} \cdot \mathrm{day}^{-1}$ ), while $C$ is

227 the $95 \%$ confidence upper limit of the metal or metalloid concentration (in $\mathrm{mg} \cdot \mathrm{kg}^{-1}$ ), $\operatorname{Ing} R$ is the 228 dust ingestion rate (200 $\mathrm{mg} \cdot$ day $^{-1}$ for children under 6 and $100 \mathrm{mg} \cdot$ day $^{-1}$ for adults), $E_{\text {freq }}$ is the 229 exposure frequency (days $\cdot \mathrm{year}^{-1}$ ), $E_{d u r}$ is the exposure duration (years), BW is the average body 230 weight, and AT is the average time of exposure $(E D \times 365$ days for non-chronic exposure; $70 \times$ 231365 days for chronic exposure). As suggested by the US EPA (1989) the hazard index by oral 232 ingestion ( $\mathrm{HI}_{\text {ingestion }}$; Equation 4$)$ of the Antofagasta dust was preliminarily obtained using the $233 C D I_{\text {ingestion }}$ and reference doses $(R f D)$ from literature (As: US EPA \& IRIS (1991); Ba: Dallas \& 234 Williams (2001); Cd: US EPA \& IRIS (1989); Co: Finley et al. (2012); Cr(VI): US EPA \& IRIS 235 (1998); Mo: US EPA \& IRIS (1992); Ni (soluble salts of Ni): US EPA (1991); V: RAIS (1991); 236 Zn: US EPA \& IRIS (2005)). For $\mathrm{Cu}$, the $\mathrm{HI}_{\text {ingestion }}$ was obtained with the minimal risk level 237 (MRL; ATSDR, 2004), and for $\mathrm{Pb}$, the $H I_{\text {ingestion }}$ was not calculated because the $R f D_{P b}(\mathrm{~Pb}$ 238 reference dose) does not exist given that $\mathrm{Pb}$ is considered toxic at any concentration (US EPA, 239 2004).

$240 \quad H I_{\text {ingestion }}=\frac{C D I_{\text {ingestion }}}{R f D}$

241 In Equation 4, $H I_{\text {ingestion }}$ is the hazard index (by ingestion), $C D I_{\text {ingestion }}$ is the chemical daily intake 242 (by ingestion), and $R f D$ is the reference dose (US EPA, 1989). The greater the value of $H I$ above 243 unity (1), the greater the level of concern. Therefore $H I \leq l$ suggests unlikely adverse health 244 effects whereas $H I>1$ suggests the probability of adverse health effects (Luo et al., 2012; 245 Massey, Kulshrestha \& Taneja, 2013). For As, in the case of $H I>1$, health effects have been 246 related to cellular necrosis and cancer (US EPA \& IRIS, 1991).

\section{$247 \quad 2.4$ Bioaccessibility assay}

248 Health effects caused by exposure to the different components of dust mainly occur by ingestion 
249 of small-sized particulate matter (PM). Fine and ultrafine particles (lower than $2.5 \mu \mathrm{m}$ in

250 diameter; $\leq \mathrm{PM}_{2.5}$ ) present a health risk due to their entrance into the bloodstream from lung

251 alveoli, whereas larger particles $\left(>\mathrm{PM}_{2.5}\right)$ are momentarily retained in the bronchi and

252 bronchiole and are then expelled from the cilia of epithelial cells in the respiratory tract.

253 Subsequently, these particles are swallowed, and once in the stomach, gastric hydrochloric acid

254 at $\mathrm{pH} 2.0$ partially solubilize components which constitute the bioaccessible fraction of the dust

255 used to estimate the amount available for absorption across the gastrointestinal barrier (Bradham

256 et al., 2017). Therefore, a higher bioaccessibility of a contaminant element signifies that a larger

257 fraction will enter the human bloodstream.

258 To compliment the health risk assessment, a bioaccessibility assay was performed at 3 sites close

259 to the Antofagasta Port. Following existent methodologies (eg., Cortés et al., 2015), this assay

260 was performed in the dust fraction of a diameter less than $63 \mu \mathrm{m}$ (mesh \#230). Dust was digested

261 with chloridric acid at a $\mathrm{pH}$ of 2 and a temperature of $37^{\circ} \mathrm{C}$, for 2 hours, in order to resemble the

262 digestive conditions of the human stomach. Three replicates were used for every sample and the

263 standard recovery varied between $82 \%$ and $98 \%$. Elements within the digested residue were

264 quantified by ICP-OES.

2653 RESULTS

$266 \quad 3.1$ Statistical summary and spatial variation

267 Compared to the UCC mean concentrations (Rudnick \& Gao, 2003; Table 3), Antofagasta dust

268 concentrations of $\mathrm{Co}, \mathrm{Cr}, \mathrm{Mn}$, and V from 2014 and 2016 were similar, whereas $\mathrm{Ba}$ and Ni were

269 lower. These elements also exhibited a lower relative standard deviation $(\sigma \div$ mean $\times 100)$ when

270 compared to the mean concentration of all considered data. This variability ranged from $21 \%$ to

$27169 \%$ for $\mathrm{V}$ and $\mathrm{Ba}$, respectively (Table 3). Comparing concentrations from 2014 and 2016 at 
272 locations within a $0.5 \mathrm{~km}$ distance from the Antofagasta Port, mean values of $\mathrm{Ba}(+96 \%)$, Co $273(+71 \%), \mathrm{Ni}(+33 \%)$ and $\mathrm{V}(+32 \%)$ increased, and $\mathrm{Cr}(-3 \%)$ and $\mathrm{Co}(-3 \%)$ showed a slight 274 decrease.

275 The elements $\mathrm{As}, \mathrm{Cd}, \mathrm{Cu}, \mathrm{Mo}, \mathrm{Pb}$, and $\mathrm{Zn}$ showed mean concentrations that were 2 (As, Mo, and $276 \mathrm{~Pb})$ and $3(\mathrm{Cd}, \mathrm{Cu}$, and $\mathrm{Zn})$ orders of magnitude higher than the UCC. They also displayed the

277 highest relative standard deviations when all data were considered, ranging from $91 \%$ for $\mathrm{Cu}$ and $278 \mathrm{Zn}$ to $120 \%$ for $\mathrm{Pb}$ (Table 3). Concentrations of $\mathrm{As}(-49 \%), \mathrm{Cu}(-17 \%)$, and $\mathrm{Pb}(-87 \%)$ showed a

279 significant decrease in their mean values between 2014 and 2016, while $\mathrm{Cd}(+44 \%)$, Mo (+72\%), 280 and $\mathrm{Zn}(+56 \%)$ showed increased mean concentrations within a $0.5 \mathrm{~km}$ radius of the Antofagasta 281 Port (Table 3). Despite the high observed variability in element concentrations of the 282 Antofagasta dust, the highest concentration values of $\mathrm{As}, \mathrm{Cd}, \mathrm{Cu}, \mathrm{Mo}, \mathrm{Pb}$, and $\mathrm{Zn}$ were evident 283 near the facility (Fig. 3). Negative Pearson correlations between these elements and distance to 284 the Antofagasta Port range between -0.28 and -0.43 (considering all data), indicating that the 285 element concentrations decreased with distance from the port (Table 3). The elements $\mathrm{Co}, \mathrm{Ni}$, 286 and V showed slightly higher values near Antofagasta Port that are different from $\mathrm{Ba}, \mathrm{Cr}$, and 287 Mn which tended to increase as a function of distance from the port. However, all concentrations 288 are within the same order of magnitude. For these elements, Pearson correlations are lower than 2890.57 (Table 3).

290 Finally, the principal component analysis of the data identified two main associations. These

291 were related to samples located less than $0.5 \mathrm{~km}$ and greater than $0.5 \mathrm{~km}$ away from the 292 Antofagasta Port (Fig. 4).

293 3.2 Contaminants and sources

294 Results for the $\mathrm{I}_{\mathrm{geo}}$ index (Muller, 1979) are shown in Table 4. Two groups are clearly observed: 
295 the non-contaminants, including $\mathrm{Ba}, \mathrm{Co}, \mathrm{Cr}, \mathrm{Mn}, \mathrm{Ni}$, and $\mathrm{V}$, and the contaminants, which include

$296 \mathrm{As}, \mathrm{Cd}, \mathrm{Cu}, \mathrm{Mo}, \mathrm{Pb}$, and $\mathrm{Zn}$. With the exception of As indices calculated with a soil background,

297 all elements classified as contaminants are considered extreme contaminants within a $0.5 \mathrm{~km}$

298 distance from the Antofagasta Port (Table 4).

299 The enrichment factor (EF) results are summarized in Table 5. The same elements classified as

300 non- contaminants exhibit low EFs (generally lower than 3), indicating that they likely originate

301 from volcanic, intrusive, metamorphic rocks, dikes, or soils within the immediate areas of

302 Antofagasta. Conversely, contaminant elements exhibit higher EFs near the port, which suggests

303 that the source is not related to the geology of Antofagasta and is more concentrated close to this

304 facility (Table 5).

$305 \quad 3.3$ Health risk assessment and bioaccessibility of dust

306 The CDIs and HIs related to Antofagasta dust ingestion are summarized in Table 6. As

307 previously defined, if a child between 0 to 6 years of age ingests $200 \mathrm{mg} \cdot \mathrm{day}^{-1}$ of Antofagasta

308 dust, on average, during 2 years of exposure (or from the start of operation of the galpón), the

309 HIs related to $\mathrm{As}$ and $\mathrm{Cu}$ are elevated at all sampling points, even $3 \mathrm{~km}$ away from the

310 Antofagasta Port. Conversely, $\mathrm{Cd}$ and $\mathrm{Zn}$ represent a low hazard $1 \mathrm{~km}$ and $0.5 \mathrm{~km}$ from the port,

311 respectively (Table 6b). For adults living in Antofagasta with a mean body mass of $70 \mathrm{~kg}$ that

312 consume $100 \mathrm{mg} \cdot \mathrm{day}^{-1}$ of dust, on average, over 70 years (signifying chronic exposure), As and

$313 \mathrm{Cu}$ are moderately hazardous elements within $0.5 \mathrm{~km}$ of the port and slightly hazardous within 1

$314 \mathrm{~km}$ of the facility (Table 6b). With the exception of $\mathrm{Pb}$, which does not have a $R f D$ value, given

315 that it is highly hazardous at any concentration (US EPA, 2004), the elements Ba, Co, Cr, Mn,

$316 \mathrm{Mo}, \mathrm{Ni}$, and $\mathrm{V}$ are not considered harmful to infants and adults.

317 Results of the mean bioaccessibility of contaminant elements at 3 sites close to the port are 
318 presented in Table 7 . It is apparent that As has the highest bioaccessibility (50\%), signifying that

319 it can more readily enter the human bloodstream in comparison to the other contaminant

320 elements. The highest bioaccessibility of As is followed by $\mathrm{Pb}(26 \%), \mathrm{Cu}(20 \%), \mathrm{Zn}(16 \%)$, and

$321 \mathrm{Cd}(10 \%)$, whereas Mo does not present a heightened potential of bioaccessibility (Table 7).

3224 DISCUSSIONS

\subsection{Comparison to worldwide city dust}

324 The results of this analysis of existing street dust data from Antofagasta indicate that $\mathrm{As}, \mathrm{Cd}, \mathrm{Cu}$,

$325 \mathrm{Mo}, \mathrm{Pb}$, and $\mathrm{Zn}$ are contaminants and their notably high concentrations are not related to the

326 geochemistry of outcrops or soil of the city. To compare these results in a national and

327 international context, the mean and standard deviation of these contaminants and the non-

328 contaminant elements (Ba, $\mathrm{Co}, \mathrm{Cr}, \mathrm{Mn}, \mathrm{Ni}$, and $\mathrm{V}$ ) were compared to: (i) dust accumulated in

329 Platanus orientalis leaves of the main east-west highway of Santiago (Alameda), the capital of

330 Chile (13 sites, Tapia et al., 2009), (ii) resuspended dust from Fushun, China (17 dust samples

331 collected from unfrequently cleaned windowsills or plat floors), a coal-based city (Kong et al.,

332 2011), (iii) street dust from Baoji, an important industrial city in Northwest China which has

333 experienced a rapid urbanization and industrialization during the last decades ( $\mathrm{Lu}$ et al., 2009),

334 (iv) street dust from Zhuzhou, a heavily industrialized city in central China (Li et al., 2013), (v)

335 dust from the industrial area of Qingshan district (QS) in Wuhan, China, one of the largest

336 metropolises in that country (Zhu et al., 2013), and (vi) road dust from the Islamabad

337 Expressway (Faiz et al., 2009), one of the busiest roads in the capital of Pakistan (Table 8).

338 The concentrations of the contaminants $\mathrm{As}, \mathrm{Cu}$, and $\mathrm{Zn}$ in Antofagasta dust are strikingly high in

339 comparison to street or urban dusts from heavily industrialized cities of Chile, China, or

340 Pakistan. Mn and Mo concentrations are similar to Santiago city dust, while $\mathrm{Pb}$ and $\mathrm{Cd}$ 
341 concentration values are lower and comparable, respectively, to Zhouzhou dust. On the contrary,

342 resuspended dust from the coal-based city of Fushun contains the highest values of Co, Cr, and

$343 \mathrm{Ni}$, and dust from the industrial QS district presents the highest concentrations of Ba (Table 8).

$344 \quad 4.2$ Anthropogenic sources of contamination

345 Based on the results of this study, there exists a strong correlation in Antofagasta between

346 elevated concentrations of several key contaminants and their proximity to the Antofagasta Port.

347 This indicates that materials stored in the port represent a source of $\mathrm{As}, \mathrm{Cd}, \mathrm{Cu}, \mathrm{Mo}, \mathrm{Pb}$, and $\mathrm{Zn}$

348 that is measurable in Antofagasta city dust. In Table 4, these contaminants show higher $\mathrm{I}_{\text {geo }}$

349 values near the port; therefore, contamination increases close to the facility. In addition, their

350 EFs were higher near the port (Table 5). This relationship is not shown by the non-contaminant

351 elements (Tables 4 and 5), as some of their EFs are equal to 1, indicating that Ba might originate

352 from volcanics, $\mathrm{Co}$ from volcanics or intrusives, $\mathrm{Cr}$ from intrusives or soil, $\mathrm{Mn}$ from

353 metamorphic, volcanic, or intrusive rocks, Ni from soil, and V from all rocks of the city (Table

354 5). Conversely, EFs obtained for $\mathrm{As}, \mathrm{Cd}, \mathrm{Cu}, \mathrm{Mo}, \mathrm{Pb}$, and $\mathrm{Zn}$ were generally greater than 20 ,

355 indicating that their sources cannot be from rocks and soil present in the city (Table 5). To

356 support this conclusion, other studies conducted in marine environments of the Bay of

357 Antofagasta have showed that enrichment of metals such as $\mathrm{Cu}, \mathrm{Pb}$ and $\mathrm{Zn}$ in coastal waters,

358 bottom sediments, and benthic organisms are related to industrial activities developed along the

359 coastal border of the bay (Salamanca et al., 2000; Lépez, Furet \& Aracena, 2001; Salamanca,

360 Jara \& Rodríguez, 2004; Valdés et al., 2010, 2011, 2014, 2015; Calderón \& Valdés, 2012).

361 As potential sources of anthropogenic contamination, Chilean $\mathrm{Cu}$ concentrates and Bolivian

362 stockpiles are addressed individually in the two following subsections.

\section{4.2.1 Cu concentrate}


364 Chilean $\mathrm{Cu}$ concentrates are notably rich in As, containing on average from $1 \%$ or 10000

$365 \mathrm{mg} \cdot \mathrm{kg}^{-1}$ (Cantallopts, 2015) to $2.5 \%$ or $25000 \mathrm{mg} \cdot \mathrm{kg}^{-1}$ (Herreros et al., 2003) of this metalloid,

366 indicating that the $\mathrm{Cu}$ concentrate stored in the Antofagasta Port represents an important source

367 of As. Indeed, the average As in Antofagasta dust (239 $\left.\mathrm{mg} \cdot \mathrm{kg}^{-1}\right)$ represents only $2.4 \%$ of the

368 average As concentration of Chilean $\mathrm{Cu}$ concentrate $\left(10000 \mathrm{mg} \cdot \mathrm{kg}^{-1}\right)$.

369 The Sierra Gorda Mine, which is situated within a Cu-Mo porphyry deposit (Brunetti, 2011), 370 produces 120000 tons of $\mathrm{Cu}, 50$ million pounds of $\mathrm{Mo}$, and 10 million pounds of $\mathrm{Au}$ each year

371 (Sierra Gorda website), meaning that the $\mathrm{Cu}$ concentrates of this mine (and the materials stored

372 in the galpón) are rich in Mo. This is supported by the fact that many of the most important

373 porphyry copper deposits of Chile exploit Mo as a byproduct; for instance, there has been an

374 average of (i) 9212 tons every year, since 1997, of Mo in the concentrate of Chuquicamata and

375 Radomiro Tomic and (ii) 8572 tons, since 2000, in the concentrate of Los Pelambres

376 (COCHILCO, 2016). Chilean porphyries can also be related to $\mathrm{Zn}$ anomalies (e.g., La

377 Escondida; Garza, Titley \& Pimentel, 2001). Therefore, $\mathrm{Cu}$ concentrate stored in the Antofagasta

378 Port likely also acts as a source of the high concentrations of As, Mo, and $\mathrm{Zn}$ recorded in street 379 dust.

\section{$380 \quad$ 4.2.2 Bolivian stockpiles}

381 The elementary concentrations of stockpiles from Bolivia that were stored in the port until the

382 1990s are unknown, yet they contained $\mathrm{Pb}$ and $\mathrm{Zn}$ (El Mercurio, 2010). This reflects the fact that

383 Bolivian mineral deposits are typically polymetallic. For instance, Cerro Rico from Potosí was

384 the largest silver ( $\mathrm{Ag})$ deposit known and is associated with base minerals such as cassiterite

$385\left(\mathrm{SnO}_{2}\right)$, sphalerite $((\mathrm{Zn}, \mathrm{Fe}) \mathrm{S})$, and galena $(\mathrm{PbS})$; the San Cristóbal District contains $2.0 \mathrm{oz} \cdot \mathrm{t}^{-1} \mathrm{Ag}$,

$3861.67 \% \mathrm{Zn}$, and $0.58 \% \mathrm{~Pb}$ with minerals such as galena, sphalerite, pyrite $\left(\mathrm{FeS}_{2}\right)$, and chalcopyrite 
$387\left(\mathrm{CuFeS}_{2}\right)$; and Pulacayo hosts minerals such as sphalerite, tetrahedrite $\left((\mathrm{Cu}, \mathrm{Fe})_{12} \mathrm{Sb}_{4} \mathrm{~S}_{13}\right)$,

388 freibergite $\left((\mathrm{Ag}, \mathrm{Cu}, \mathrm{Fe})_{12}(\mathrm{Sb}, \mathrm{As})_{4} \mathrm{~S}_{13}\right)$, argentiferous galena, and chalcopyrite (Kamenov,

389 Macfarlane \& Riciputi, 2002). These polymetallic mineral ores are related to $\mathrm{Pb}, \mathrm{Zn}$, and $\mathrm{Cu}$,

390 which could explain the presence of these elements in dust sampled in close proximity to the

391 Antofagasta Port. In addition, minerals containing $\mathrm{Zn}, \mathrm{Pb}$, and $\mathrm{Cu}$ are natural sources of $\mathrm{Cd}$

392 (ATSDR, 2012), which could explain its enrichment near the Antofagasta Port.

\section{$393 \quad$ 4.2.3 Health risk}

394 The bioaccessibility of dust components was investigated in solid materials (i.e. mud and

395 sediment) of Chañaral, Atacama Region (300 km south of Antofagasta), an environment similar

396 to Antofagasta, revealing that the bioaccessibility percentages of some contaminant elements

397 range from: $26 \%$ to $49 \%$ for $\mathrm{As}, 24 \%$ to $84 \%$ for $\mathrm{Cu}, 67 \%$ to $96 \%$ for $\mathrm{Pb}, 19 \%$ to $79 \%$ for $\mathrm{Zn}$

398 (Cortés et al., 2015). In the case of the 3 sites studied in relation to dust of the Antofagasta Port

399 (Table 7), As is highly bioaccessible (50\%), followed by $\mathrm{Pb}(26 \%)$ and $\mathrm{Cu}(20 \%)$. These

400 significant bioaccessibilities are supported by the fact that As and $\mathrm{Cu}$ show the highest HIs in the

401 street dust (Table 6b).

402 The health effects of chronic exposure to toxic metals and metalloids are well-known. For

403 example, following chronic exposure of 30 or more years to As, the probability of mortality

404 increases dramatically due to lung and bladder cancers. In addition, prenatal or infant exposure to

405 low levels of these elements, through the mechanism of epigenetic imprinting, can cause

406 irreversible biochemical changes that promote the development of various organic diseases or

407 neurobehavioral alterations in later years (Tchernitchin et al., 2013; Tchernitchin \& Gaete,

408 2015). Also, the prenatal exposure to As increases the probability of mortality due to

409 bronchiectasis between the ages of 30 to 49 years (Smith \& Steinmaus, 2009); prenatal or infant 
410 exposure to $\mathrm{Pb}$ affects reproductive functions, decreases intelligence, and causes serious

411 neurobehavioral changes in later stages of life (Tchernitchin et al., 2013).

\section{$412 \quad 4.3$ Recommendations and considerations}

413 Street dust from Antofagasta likely represents the highest recorded concentrations of $\mathrm{As}, \mathrm{Cu}$, and

$414 \mathrm{Zn}$ in city dust worldwide. This result is not surprising, given that Chile is the most important

415 producer of $\mathrm{Cu}$, Chilean ores, and concentrates, acting as a plentiful source of As, Mo, and to a 416 lesser extent Zn. Mining development in Chile continues to be predominant; for example, La

417 Negra Industrial Complex has grown to 200 hectares and 120 companies, including a Cu smelter.

418 Previous studies, such as Ruiz-Rudolph et al. (2016), show that Chilean communes with this type

419 of facility suffer higher mortality rates.

420 Although the Antofagasta Port is an important employer in the city, storing $\mathrm{Cu}$ concentrate and 421 polymetallic stockpiles there for long-term periods is not appropriate due to health concerns.

422 These materials have caused disease in children in the past (Sepúlveda, Vega \& Delgado, 2000) 423 and continue to cause elevated concentrations of pollutants in children's blood and urine 424 (Vergara, 2015). The results of sampling show that street dust contains concentrations of 425 dangerous contaminants that are high enough to threaten the health of people (especially 426 children) living and working in close proximity to Antofagasta Port. A precautionary measure 427 previously undertaken as of 2010 for some concentrates stored in Portezuelo is that they have 428 been and are now transported to the Antofagasta Port by hermetically sealed and cleaned trucks 429 (MTT, 2015). Nonetheless, once stationary in Antofagasta, concentrates could be displaced by 430 wind that moves preferentially in the SW direction; hence, special attention must be paid to the 431 dispersion of contaminants from concentrates and stockpiles to the NE, especially during windy 432 days. 
433 As seen in resuspended dust from Fushun, China, some elements can be highly accumulated in

434 dust (e.g., Cr $5334 \pm 10667 \mathrm{mg} \cdot \mathrm{kg}^{-1}$; Kong et al., 2011), especially when it is from long-term

435 uncleaned surfaces. Antofagasta is located within the world's driest desert, and as such, there is a

436 very low probability for rain to remove dusts. Cleaning surfaces with wet mops twice a month

437 and frequently washing children's hands in locations close to the port are precautionary measures

438 that can be taken on an individual level to prevent the ingestion of city dust, lowering $\mathrm{Pb}$ values

439 in blood (Charney et al., 1983).

440 As a long-term goal, existing and prospective developments located in close proximity to the

441 port should consider the high risk of contamination and develop relevant strategies to minimize

442 exposure to contaminated dust. Operations within the port itself should be modified (through

443 regulations, safety guidelines, and practical measures). Additionally, it will be important for the

444 regional and national governments to invest in suitable health care (e.g. the training of specialists

445 and development of suitable medical facilities).

446 The future management and prevention of contamination in Antofagasta could also be

447 strengthened by the implementation of a local high-quality geochemistry laboratory that allows

448 for fast, efficient, and accurate measurements of contaminants through the utilization of specific

449 environmental matrices where pollutant speciation can be efficiently determined. Considering

450 that the mining industry will continue to be a profitable venture in Chile that provides jobs and

451 income as other commodities become extensively exploited in this region (e.g., Li), the

452 implementation and management of a laboratory of this type is necessary in this growing and

453 highly contaminated city and region.

454 Finally, it is important to note that the contamination and problems described are likely not

455 restricted to Antofagasta, or to Chile. Wherever metals are extracted, stored, and transported, 
456 there is a risk that workers and the public can be exposed to contamination and it is important

457 that this is recognized by all parties. Chile is rapidly moving towards the status of a developed

458 country, however environmental protection measures have not yet developed at the same rate as

459 its economy. Industrial regulations must ensure safe levels of pollutants as is defined in the

460 Constitution of Chile which states that Chilean citizens "have the right to live in a

461 contamination-free environment" (Gobierno de Chile, 1980).

\section{CONCLUSIONS}

463 Main conclusions related to Antofagasta dust contamination are summarized below while

464 considering the local geology, health risks, and bioaccessibility of the contaminant elements.

465 These items are followed by potential short- and long-term recommendations and considerations

466 that could reduce associated adverse health impacts to Antofagasta residents.

467 1. Street dust from the city of Antofagasta in northern Chile contains $\mathrm{Ba}, \mathrm{Co}, \mathrm{Cr}, \mathrm{Mn}, \mathrm{Ni}$,

468 and $\mathrm{V}$ that likely originate from intrusive, volcanic, metamorphic rocks, dikes, or soil of 469 the city.

470 2. Antofagasta city dust is contaminated with $\mathrm{As}, \mathrm{Cd}, \mathrm{Cu}, \mathrm{Mo}, \mathrm{Pb}$, and $\mathrm{Zn}$, and this 471 contamination likely originates from the Antofagasta Port (an anthropogenic source).

472 3. The mean concentrations of As (239 $\left.\mathrm{mg} \cdot \mathrm{kg}^{-1}\right), \mathrm{Cu}\left(10821 \mathrm{mg} \cdot \mathrm{kg}^{-1}\right)$, and $\mathrm{Zn}(11869$ $473 \mathrm{mg} \cdot \mathrm{kg}^{-1}$ ) are likely the highest in street dust worldwide.

474 4. Heightened bioaccessibility in Antofagasta dust was found for $\mathrm{As}, \mathrm{Cu}$ and $\mathrm{Pb}$, indicating that comparatively high fractions could be absorbed into the human bloodstream.

5. The bioaccessibility and hazard indices indicate that $\mathrm{As}, \mathrm{Cu}$, and $\mathrm{Pb}$ in dust represent a health risk to children or adults chronically exposed to Antofagasta dust.

478 Potential recommendations and considerations include: 
479

480

481

482

483

484

485

486

487

488

489

490

491

492

493

494

495

496

497

498

499

500

501

\section{Short term:}

- Discussions with regulators and relevant parties in industry regarding the significance of the results in relation to the city's occupants. Prospective developments and businesses in close proximity to the Antofagasta Port should be fully aware of the risk of contamination.

- Houses and children living in close proximity to the Antofagasta Port should be constantly cleaned to avoid dust ingestion.

2. Long term:

- Stricter regulations on a national or regional level should be adopted to reduce dustborne contamination. Also, businesses, schools, and prospective developments in close proximity to the port should develop relevant long-term strategies to minimize exposure to contaminated dust.

- Polymetallic stockpiles and $\mathrm{Cu}$ concentrates should not be kept in the Antofagasta Port for long-term periods.

- Investments should be made in medical training and infrastructure to properly remedy potential health impacts.

- The implementation of a real-time monitoring program and high-quality geochemistry laboratory should be considered to improve the quantification of contaminant elements and their speciation in Antofagasta dust.

\section{ACKNOWLEDGMENTS}

This study would have not been possible without help from the following: Verónica Oliveros and collaborators for facilitating the access to unpublished data (from Oliveros et al., 2007), Mario Pereira Acevedo and Manuel Arenas of the Servicio Nacional de Geología y Minería for 
502 providing 1:50000 Antofagasta maps (SERNAGEOMIN, 2014), the Instituto de Salud Pública

503 and Colegio Médico for providing dust data (ISP, 2014; Tchernitchin and Bolados, 2016),

504 Brandon Schneider for English improvement, and Isel Cortés and CENMA for laboratory quality

505 control information. We also thank David Massey and two anonymous reviewers for their

506 valuable comments and suggestions.

507 REFERENCES

508 Aroca P. 2001. Impacts and development in local economies based on mining: the case of the

509 Chilean II region. Resources Policy 27:119-134. DOI: 10.1016/S0301-4207(01)00013-7.

510 ATSDR 2004. ATSDR - Toxicological Profile: Copper. Available at

511 https://www.atsdr.cdc.gov/ToxProfiles/tp.asp?id=206\&tid=37 (accessed March 22, 2018).

512 ATSDR 2012. ATSDR - Public Health Statement: Cadmium. Available at 513 https://www.atsdr.cdc.gov/phs/phs.asp?id=46\&tid=15 (accessed January 29, 2018).

514 Bradham KD., Nelson CM., Kelly J., Pomales A., Scruton K., Dignam T., Misenheimer JC., Li

515 K., Obenour DR., Thomas DJ. 2017. Relationship Between Total and Bioaccessible Lead

516 on Children's Blood Lead Levels in Urban Residential Philadelphia Soils. Environmental

517 science \& technology 51:10005-10011. DOI: 10.1021/acs.est.7b02058.

518 Broughton E. 2005. The Bhopal disaster and its aftermath: a review. Environmental Health 4:6.

519 DOI: $10.1186 / 1476-069 X-4-6$.

520 Brunetti P. 2011. Geología, Alteración y Mineralización del Yacimiento Tipo Pórfido Cuprífero

521 Pampa Lina, Distrito Sierra Gorda, Región Antofagasta. Memoria para optar al título de

522 geóloga Thesis. Santiago: Universidad de Chile. Available at:

523 http://repositorio.uchile.cl/handle/2250/104305 (accessed September 10, 2016).

524 Calderón C., Valdés J. 2012. Contenido de metales en sedimentos y organismos bentónicos de la 
bahía San Jorge, Antofagasta, Chile. Revista de biología marina y oceanografía 47:121133. DOI: $10.4067 / \mathrm{S} 0718-19572012000100011$.

527 Cantallopts J. 2015. Chile en el mercado de los concentrados de cobre: Elementos para un análisis estratégico. Available at: $\quad$ http://www.revistaquimica.cl/wpcontent/uploads/2015/12/Chile-en-el-mercado-de-concentrados-de-cobre.-JCantallopts1.pdf (accessed June 25, 2016).

531 CENMA 2014. Diagnóstico regional de suelos abandonados con potencial presencia de contaminantes. Available at: $\quad$ http://www.cenma.cl/Pagina\%20web-LQA/4Gesti\%C3\%B3n\%20de\%20SPPC/2014-FNDR\%20AntofagastaINFORME\%20FINAL.pdf (accessed March 15, 2016).

535 Censo. 1895. Sesto censo jeneral de la población de Chile._Available at: 536 http://www.memoriachilena.cl/602/w3-article-82450.html (accessed April 12, 2016).

537 Censo. 1960. Población del país, Características básicas de la población._Available at: 538 http://www.memoriachilena.cl/602/w3-article-86206.html (accessed April 12, 2016).

539 Charney E., Kessler B., Farfel M., Jackson D. 1983. Childhood Lead Poisoning. New England $540 \quad$ Journal of Medicine 309:1089-1093. DOI: 10.1056/NEJM198311033091804.

541 Clarke KR., Gorley RN. 2006. PRIMER v6: User Manual/Tutorial. Plymouth, UK: Plymouth $542 \quad$ Marine Laboratory.

543 COCHILCO. 2014. Estadísticas - Producción Minera. Available at 544 http://www.cochilco.cl/estadisticas/produccion.asp (accessed July 8, 2016).

545 COCHILCO 2016. Anuario de estadísticas del cobre y otros minerales 1997-2016. Available at: 546 https://www.cochilco.cl/Paginas/Estadisticas/Publicaciones/Anuario.aspx (accessed September 10, 2017). 
548 Cortés I., Ríos J., Gaete L., Tchernitchin A. 2015. Metales pesados en muestras ambientales de la

549 Región de Atacama. Situación postaluviones. In: Geología para el siglo XXI. La Serena, $550 \quad$ Chile, $302-305$.

551 Dallas CE., Williams PL. 2001. Barium: rationale for a new oral reference dose. Journal of 552 Toxicology and Environmental Health. Part B, Critical Reviews 4:395-429. DOI: 10.1080/109374001753146216.

554 De Gregori I., Fuentes E., Rojas M., Pinochet H., Potin-Gautier M. 2003. Monitoring of copper, arsenic and antimony levels in agricultural soils impacted and non-impacted by mining activities, from three regions in Chile. Journal of environmental monitoring: JEM 5:287-

De Solminihac H., Gonzales LE., Cerda R. 2017. Copper mining productivity: Lessons from Chile. Journal of Policy Modeling. DOI: 10.1016/j.jpolmod.2017.09.001.

Devell L., Tovedal H., Bergström U., Appelgren A., Chyssler J., Andersson L. 1986. Initial 561 observations of fallout from the reactor accident at Chernobyl. Nature 321:192-193. DOI: $10.1038 / 321192 \mathrm{a} 0$.

Dubey CS., Sahoo BK., Nayak NR. 2001. Chromium (VI) in Waters in Parts of Sukinda 564 Chromite Valley and Health Hazards, Orissa, India. Bulletin of Environmental Contamination and Toxicology 67:541-548. DOI: 10.1007/s001280157.

El Mercurio. 2010. Urgentes medidas por contaminación en "Ruta del Plomo" en Antofagasta. El 00523.html (accessed July 8, 2016).

570 Ergin M., Saydam C., Baştürk Ö., Erdem E., Yörük R. 1991. Heavy metal concentrations in 
571

572

573

574

575

576

577

578

579

580

581

582

583

584

585

586

587

588

589

590

591

592

593

surface sediments from the two coastal inlets (Golden Horn Estuary and İzmit Bay) of the northeastern Sea of Marmara. Chemical Geology 91:269-285. DOI: 10.1016/00092541(91)90004-B.

Faiz A., Weaver C., Walsh M. 1996. Air Pollution from Motor Vehicles Standards and Technologies for Controlling Emissions. Washington: The World Bank. Available at: http://documents.worldbank.org/curated/en/606461468739185298/Air-pollution-frommotor-vehicles-standards-and-technologies-for-controlling-emissions (accessed March 15, 2018).

Finley BL., Monnot AD., Paustenbach DJ., Gaffney SH. 2012. Derivation of a chronic oral reference dose for cobalt. Regulatory toxicology and pharmacology: RTP 64:491-503. DOI: 10.1016/j.yrtph.2012.08.022.

Fuentes G., Viñals J., Herreros O. 2009. Hydrothermal purification and enrichment of Chilean copper concentrates. Part 2: The behavior of the bulk concentrates. Hydrometallurgy 95:113-120. DOI: 10.1016/j.hydromet.2008.05.004.

Gale R. 1987. Immediate medical consequences of nuclear accidents: Lessons from chernobyl. JAMA 258:625-628. DOI: 10.1001/jama.1987.03400050067029.

Garza RAP., Titley SR., Pimentel F. 2001. Geology of the Escondida Porphyry Copper Deposit, Antofagasta Region, Chile. Economic Geology 96:307-324. DOI: 10.2113/gsecongeo.96.2.307.

Gobierno de Chile. 1980. Constitución de la República de Chile.

Herreros O., Fuentes G., Quiroz R., Vinals J. 2003. Lixiviación de concentrados de cobre con alto contenido de arsénico en medio cloro-cloruro. Revista de metalurgia 39:90-98.

INE 2017. Cantidad de personas por sexo y edad: Total Comunal Antofagasta. Available at: 
594 http://www.censo2017.cl/mapa-resultados-comunas/ (accessed January 15, 2018).

595 ISP. 2014. Material particulado sedimentable de Antofagasta.

596 Jorquera H. 2009. Source apportionment of PM10 and PM2.5 at Tocopilla, Chile $\left(22^{\circ} 05^{\prime}\right.$ S, $\left.59770^{\circ} 12^{\prime} \mathrm{W}\right)$. Environmental Monitoring and Assessment 153:235. DOI: 10.1007/s10661$598 \quad 008-0352-0$.

599 Kamenov G., Macfarlane AW., Riciputi L. 2002. Sources of Lead in the San Cristobal, Pulacayo, 600 and Potosí Mining Districts, Bolivia, and a Reevaluation of Regional Ore Lead Isotope 601 Provinces. Economic Geology 97:573-592. DOI: 10.2113/gsecongeo.97.3.573.

602 Khan FI., Abbasi SA. 1999. Major accidents in process industries and an analysis of causes and 603 604 consequences. Journal of Loss Prevention in the Process Industries 12:361-378. DOI: 10.1016/S0950-4230(98)00062-X.

605 Kong S., Lu B., Ji Y., Zhao X., Chen L., Li Z., Han B., Bai Z. 2011. Levels, risk assessment and 606 607 sources of PM10 fraction heavy metals in four types dust from a coal-based city. Microchemical Journal 98:280-290. DOI: 10.1016/j.microc.2011.02.012.

Lépez I., Furet L., Aracena O. 2001. Población de Emerita Analoga (Stimpson 1857) en playas 609 Amarilla y Rinconada, Antofagasta: Aspectos abióticos, bióticos y concentración de cobre. Gayana (Concepción) 65:55-76. DOI: 10.4067/S0717-65382001000100008.

611 Li Z., Feng X., Li G., Bi X., Zhu J., Qin H., Dai Z., Liu J., Li Q., Sun G. 2013. Distributions, 612 sources and pollution status of 17 trace metal/metalloids in the street dust of a heavily 613 industrialized city of central China. Environmental Pollution 182:408-416. DOI: $614 \quad$ 10.1016/j.envpol.2013.07.041.

615 Lu X., Wang L., Lei K., Huang J., Zhai Y. 2009. Contamination assessment of copper, lead, 616 zinc, manganese and nickel in street dust of Baoji, NW China. Journal of Hazardous 
Materials 161:1058-1062. DOI: 10.1016/j.jhazmat.2008.04.052.

618 Lucas C. 2001. Baia Mare and Baia Borsa Accidents: Cases of Severe Transboundary Water 619 Pollution. Environmental Policy and Law 31:106.

620 Lucassen F., Franz G. 1994. Arc related Jurassic igneous and meta-igneous rocks in the Coastal 621 Cordillera of northern Chile/Region Antofagasta. Lithos 32:273-298. DOI: 10.1016/0024622 4937(94)90044-2.

623 Luo X-S., Ding J., Xu B., Wang Y-J., Li H-B., Yu S. 2012. Incorporating bioaccessibility into 624 human health risk assessments of heavy metals in urban park soils. Science of The Total 625 Environment 424:88-96. DOI: 10.1016/j.scitotenv.2012.02.053.

626 Marshall G., Ferreccio C., Yuan Y., Bates MN., Steinmaus C., Selvin S., Liaw J., Smith AH. 627 2007. Fifty-Year Study of Lung and Bladder Cancer Mortality in Chile Related to Arsenic 628 in Drinking Water. Journal of the National Cancer Institute 99:920-928. DOI: $629 \quad$ 10.1093/jnci/djm004.

630 Massey DD., Kulshrestha A., Taneja A. 2013. Particulate matter concentrations and their related 631 metal toxicity in rural residential environment of semi-arid region of India. Atmospheric 632 Environment 67:278-286. DOI: 10.1016/j.atmosenv.2012.11.002.

633 Minería Chilena. 2013. Barrio Industrial La Negra se consolida como eje estratégico de 634 servicios. Available at http://www.mch.cl/2013/07/11/barrio-industrial-la-negra-se635 consolida-como-eje-estrategico-de-servicios/ (accessed July 28, 2016).

636 Minería Chilena. 2014.Empezó producción de cobre en la mina de Sierra Gorda. Available at 637 http://www.mch.cl/2014/07/31/empezo-produccion-de-cobre-en-la-mina-de-sierra-gorda/ $638 \quad$ (accessed August 2, 2016).

639 MTT. 2015. Comisión especial investigadora de la actuación de los organismos públicos 
encargados de la salud y medio ambiente en la Comuna de Antofagasta. Available at: https://www.camara.cl/pdf.aspx?prmID=32851\&prmTIPO=DOCUMENTOCOMISION (accessed December 15, 2017).

643 Muller G. 1979. Schwermetalle in den Sedimenten des Rheins - Veränderungen seit. Umschau 644 79:778-783.

Nowrouzi M., Pourkhabbaz A. 2014. Application of geoaccumulation index and enrichment 646 factor for assessing metal contamination in the sediments of Hara Biosphere Reserve, Iran.

Oliveros V., Morata D., Aguirre L., Féraud G., Fornari M. 2007. Magmatismo asociado a subducción del Jurásico a Cretácico Inferior en la Cordillera de la Costa del norte de Chile

DOI: 10.3184/095422914X13951584546986.

RAIS. 1991. Formal Toxicity Summary for VANADIUM. Available at https://rais.ornl.gov/tox/profiles/vanadium_f_V1.html (accessed August 10, 2016).

Reddy K., Yarrakula K. 2016. Analysis of accidents in chemical process industries in the period 1998-2015. International Journal of ChemTech Research 9:177-191.

Rogers G., Hawkesworth CJ. 1989. A geochemical traverse across the North Chilean Andes: evidence for crust generation from the mantle wedge. Earth and Planetary Science Letters 91:271-285. DOI: 10.1016/0012-821X(89)90003-4.

Rudnick RL., Gao S. 2003. 3.01 - Composition of the Continental Crust A2 - Holland, Heinrich 661 D. In: Turekian KK ed. Treatise on Geochemistry. Oxford: Pergamon, 1-64.

662 Ruiz-Rudolph P., Arias N., Pardo S., Meyer M., Mesías S., Galleguillos C., Schiattino I., 
Gutiérrez L. 2016. Impact of large industrial emission sources on mortality and morbidity in Chile: A small-areas study. Environment International 92-93:130-138. DOI: 10.1016/j.envint.2016.03.036.

Rule JH. 1986. Assessment of trace element geochemistry of Hampton Roads harbor and lower 667 Chesapeake Bay area sediments. Environmental Geology and Water Sciences 8:209-219. DOI: 10.1007/BF02524948.

Salamanca MA., Camaño A., Jara B., Rodríguez T. 2000. Distribución de Cu, Pb y Zn en aguas costeras de Bahía San Jorge en el norte de Chile. Gayana (Concepción) 64:195-204. DOI: 10.4067/S0717-65382000000200009.

Salamanca MA., Jara B., Rodríguez T. 2004. Niveles de $\mathrm{Cu}, \mathrm{Pb}$ y Zn en agua y Perumytilus Purpuratus en Bahía San Jorge, Norte de Chile. Gayana (Concepción) 68:53-62. DOI: 10.4067/S0717-65382004000100005.

Sepúlveda V., Vega J., Delgado I. 2000. Exposición severa a plomo ambiental en una población infantil de Antofagasta, Chile. Revista médica de Chile 128:221-232. DOI: 10.4067/S0034-98872000000200014.

SERNAGEOMIN. 2003. Mapa geológico de Chile: versión digital._Available at: http://www.ipgp.fr/ dechabal/Geol-millon.pdf (accessed July 15, 2017).

SERNAGEOMIN. 2014. Geología para el ordenamiento territorial: área Antofagasta._Available 681 at: http://biblioteca.sernageomin.cl/opac/DataFiles/CGCH_SGA_19_text.pdf (accessed November 10, 2017).

Smith AH., Steinmaus CM. 2009. Health Effects of Arsenic and Chromium in Drinking Water: 10.1146/annurev.publhealth.031308.100143. 
686 Soldán P., Pavonič M., Bouček J., Kokeš J. 2001. Baia Mare Accident-Brief Ecotoxicological 687 Report of Czech Experts. Ecotoxicology and Environmental Safety 49:255-261. DOI: $688 \quad 10.1006 /$ eesa.2001.2070.

689 SYSTAT 2009. SYSTAT Software Inc. Richmond, CA, USA.

690 Tapia J., Arriagada C., Townley B., Luca R., Nacif D. 2009. Estudio piloto utilizando 691 propiedades magnéticas de partículas de polvo depositado en hojas de Platanus orientalis 692 L. para determinar contaminación atmosférica.

693 Tapia, J., Audry, S., Townley, B., Duprey, JL. 2012. Geochemical background, baseline and 694 origin of contaminants from sediments in the mining-impacted Altiplano and Eastern 695 Cordillera of Oruro, Bolivia. GEEA, 12(1), 3-20.

696 Tchernitchin A., Bolados A. 2016. Informe sobre material particulado sedimentable (MPS) en 697 colegios cercanos al puerto de Antofagasta, muestras 2016. Available at: http://www.colegiomedico.cl/wp-content/uploads/2016/05/MaCM16a5doc-AFB-MPScolegios-Antof-Informe-27-10-2015.pdf (accessed July 10, 2016).

701 Promote the Development of Diseases Later in Life. Biology and Medicine 7. DOI: 702 $10.4172 / 0974-8369.1000236$.

Tchernitchin A., Gaete L., Bustamante R., Sorokin Y. 2013. Adulthood Prenatally Programmed 704 Diseases: Health Relevance and Methods of Study. In: Protein purification and analysis I. Methods and applications. Hong Kong, 217-258.

Tchernitchin AN., Lapin N., Molina L., Molina G., Tchernitchin NA., Acevedo C., Alonso P. 707 2006. Human Exposure to Lead in Chile. In: Reviews of Environmental Contamination and Toxicology. Reviews of Environmental Contamination and Toxicology. Springer, New 
York, NY, 93-139. DOI: 10.1007/0-387-30638-2_4.

710 US EPA 1989. Risk assessment guidance for superfund Volume I human health evaluation

711 manual (Part A). Available at: https://www.epa.gov/risk/risk-assessment-guidance-

712 superfund-rags-part (accessed November 2, 2016).

713 US $\quad$ EPA $1991 . \quad$ Nickel, soluble salts. Available

$714 \mathrm{https} / /$ cfpub.epa.gov/ncea/iris2/chemicalLanding.cfm?substance_nmbr=271 (accessed

715 August 10, 2016).

716 US EPA O. 2004.Lead and compounds (inorganic) CASRN 7439-92-1 | IRIS | US EPA, ORD.

717 Available at https://cfpub.epa.gov/ncea/iris2/chemicalLanding.cfm?substance_nmbr=0277

$718 \quad$ (accessed August 9, 2016).

719 US EPA, IRIS 1989.Cadmium CASRN 7440-43-9 | IRIS | US EPA, ORD. Available at 720 https://cfpub.epa.gov/ncea/iris2/chemicalLanding.cfm?substance_nmbr=141 (accessed 721 August 10, 2016).

722 US EPA., IRIS. 1991.Arsenic, inorganic CASRN 7440-38-2 | IRIS | US EPA, ORD. Available at https://cfpub.epa.gov/ncea/iris2/chemicalLanding.cfm?substance_nmbr=278 (accessed

$724 \quad$ August 9, 2016).

725 US EPA, IRIS 1992.Molybdenum CASRN 7439-98-7 | IRIS | US EPA, ORD. Available at 726 https://cfpub.epa.gov/ncea/iris2/chemicalLanding.cfm?substance_nmbr=425 (accessed $727 \quad$ August 10, 2016).

728 US EPA, IRIS. 1998.Chromium(VI) CASRN 18540-29-9 | IRIS | US EPA, ORD. Available at 729 https://cfpub.epa.gov/ncea/iris2/chemicalLanding.cfm?substance_nmbr=144 (accessed $730 \quad$ August 10, 2016).

731 US EPA, IRIS 2005.Zinc and Compounds CASRN 7440-66-6 | IRIS | US EPA, ORD. Available 

at https://cfpub.epa.gov/ncea/iris2/chemicalLanding.cfm?substance_nmbr=426 (accessed August 10, 2016).

734 Valdés J., Guiñez M., Castillo A., Vega SE. 2014. Cu, Pb, and $\mathrm{Zn}$ content in sediments and 735 benthic organisms from San Jorge Bay (northern Chile): Accumulati on and 736 biotransference in subtidal coastal systems. Ciencias Marinas 40:45-58. DOI: 737 http://dx.doi.org /10.7773/cm.v40i1.2318.

738 Valdés J., Román D., Guiñez M., Rivera L., Ávila J., Cortés P., Castillo A. 2015. Trace metal 739 variability in coastal waters of San Jorge Bay, Antofagasta, Chile: An environmental 740 evaluation and statistical approach to propose local background levels. Marine Pollution 741 Bulletin 100:544-554. DOI: 10.1016/j.marpolbul.2015.08.035.

742 Valdés J., Román D., Guiñez M., Rivera L., Morales T., Ávila J., Cortés P. 2010. Distribution 743 and temporal variation of trace metal enrichment in surface sediments of San Jorge Bay, Chile. Environmental Monitoring and Assessment 167:185-197. DOI: 10.1007/s10661-

746 Valdés J., Román D., Rivera L., Ávila J., Cortés P. 2011. Metal contents in coastal waters of San 747 Jorge Bay, Antofagasta, northern Chile: a base line for establishing seawater quality 748 guidelines. Environmental Monitoring and Assessment 183:231. DOI: 10.1007/s10661$749 \quad 011-1917-x$

750 Vergara P. 2015.Contaminación de arsénico y plomo: Un conflicto que crece en Antofagasta. 751 Available at http://www.cooperativa.cl/noticias/pais/region-de-antofagasta/contaminacion752 plomo/contaminacion-de-arsenico-y-plomo-un-conflicto-que-crece-en-antofagasta/2015753 02-04/140741.html (accessed July 27, 2016).

754 Zhu Z., Sun G., Bi X., Li Z., Yu G. 2013. Identification of trace metal pollution in urban dust 
755 from kindergartens using magnetic, geochemical and lead isotopic analyses. Atmospheric 756 Environment 77:9-15. DOI: 10.1016/j.atmosenv.2013.04.053.

757 Zoller WH., Gladney ES., Duce RA. 1974. Atmospheric Concentrations and Sources of Trace 758 Metals at the South Pole. Science 183:198-200. DOI: 10.1126/science.183.4121.198. 


\section{Figure 1}

\section{Antofagasta location}

Location maps with features, at varying scales. (A) Location of the Antofagasta Region in northern Chile; (B) Main mineral deposits and mining activities within Antofagasta Region (1. Mantos de la Luna Mine; 2. Michilla Mine; 3. Juanita Mine; 4. Mantos Blancos Mine; 5. La Negra Industrial Complex; 6. Pedro de Valdivia (ex-nitrate mine); 7. El Abra Mine; 8.

Radomiro Tomic, Chuquicamata, and Ministro Hales Mines; 9. Faride, Spence, Sierra Gorda Mines, and Aconcagua treatment plant; 10. Esperanza Mine; 11. Zaldívar and La Escondida Mines; 12. Francke Mine), and Antofagasta city (black square); (C) Downtown Antofagasta. A. Port gate; B. Clínica Antofagasta (health institution); C. Parque Brasil (Children's playground); D. Commercial center; E and F. Schools (Liceo de Hombres and Liceo de Niñas, respectively); G. Housing complex; H. City Mall; I. Municipal square; J. Hospital (health institution); K. Fruit and vegetable market; L. Supermarket. The red circle represents an area with a $1 \mathrm{~km}$ distance (radius) from the port gate.
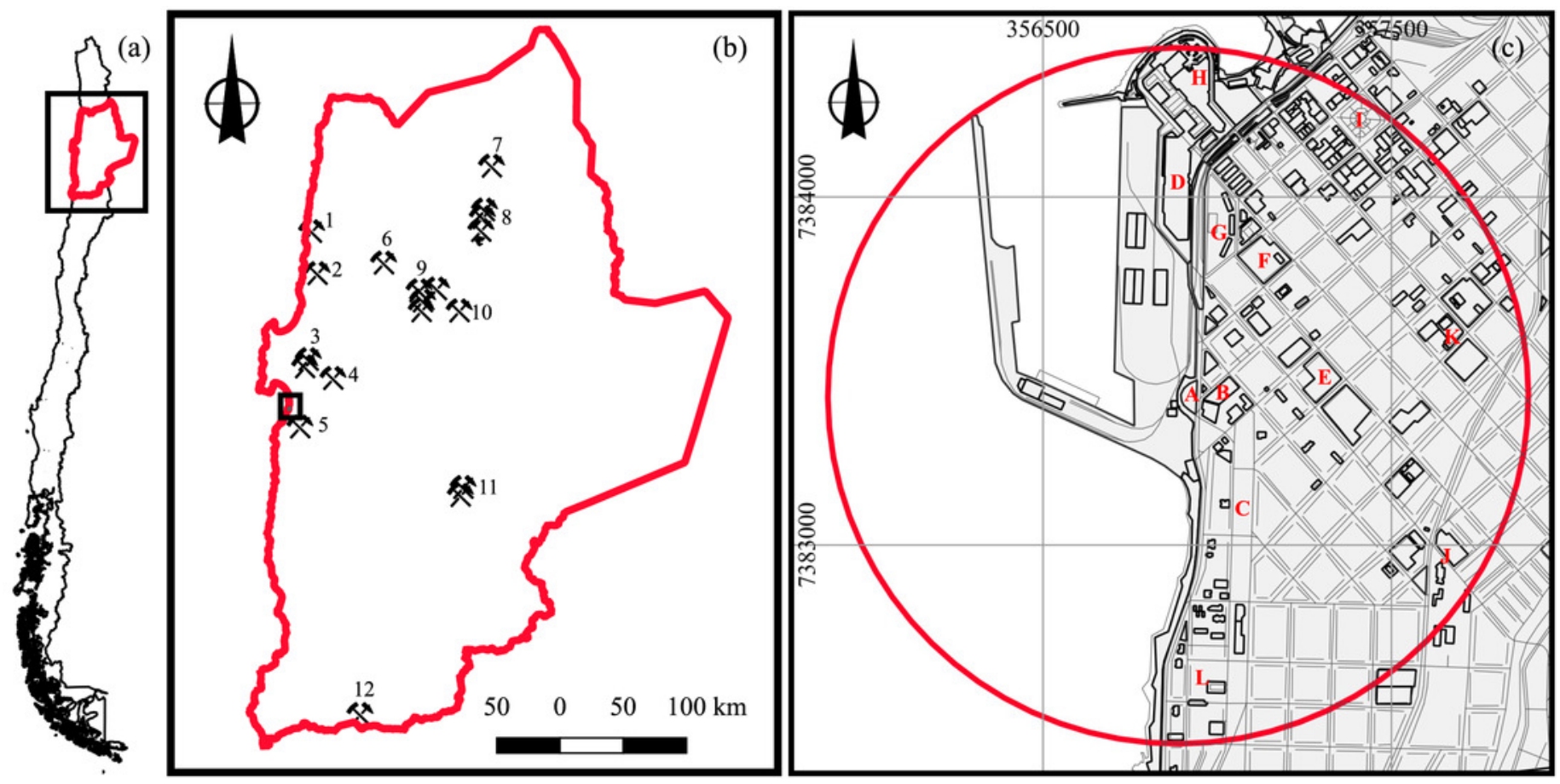


\section{Figure 2}

Antofagasta geology

Locations with geochemical data. (A) Regional volcanic, intrusive, metamorphic rocks, dikes, and soils found in the vicinity of the city of Antofagasta; (B) Local geology and dust samples from the city of Antofagasta. The red circle represents an area with a $1 \mathrm{~km}$ distance (radius) from the port. 


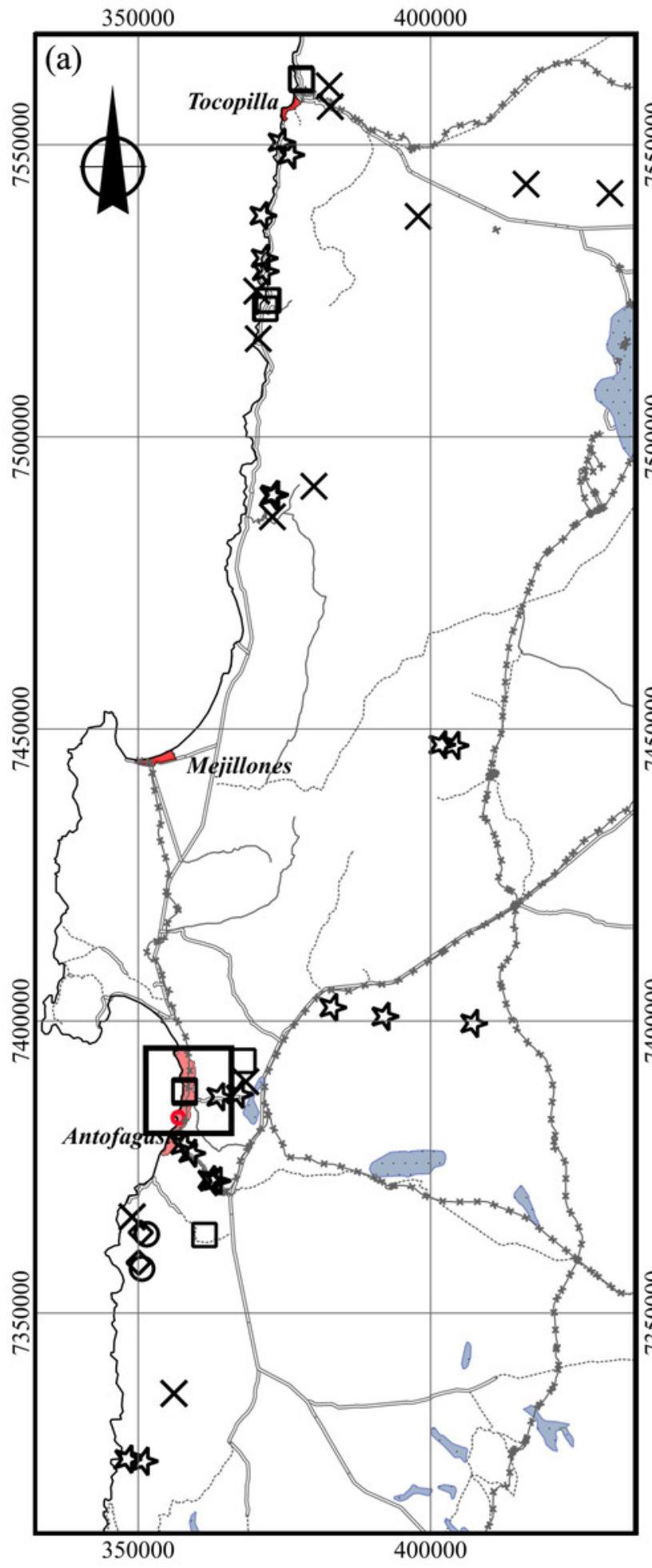

\section{Legend}

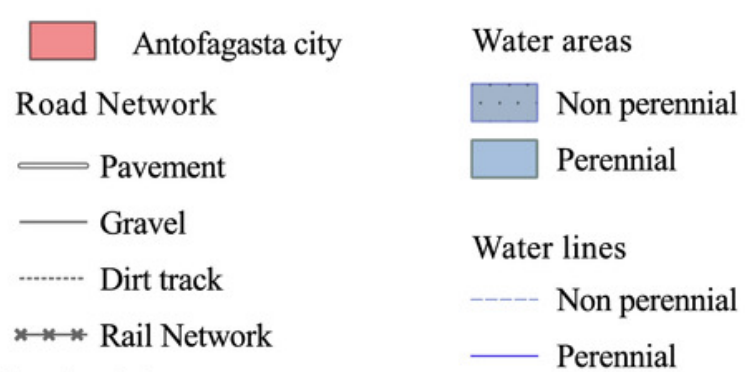

Regional data:

$\diamond$ Igneous dike

$X$ Igneous intrusive rock

Sampling sites:

Igneous volcanic rock

放 2014, Port $<5 \mathrm{~km}$

O Metamorphic rock

is $2014,0.5 \mathrm{~km}<$ Port $<1 \mathrm{~km}$

$\square$ Soil

敢 2014 , Port $>1 \mathrm{~km}$

$\diamond$ 2016, Port $<0.5 \mathrm{~km}$

Geology

$\square$ Quaternary alluvial and eolian deposits

- Miocene to Pliocene marine and continental sedimentary sequencies

Cretaceous intrusive outcrops

$\checkmark$ Jurassic igneous volcanic sequences of La Negra Formation

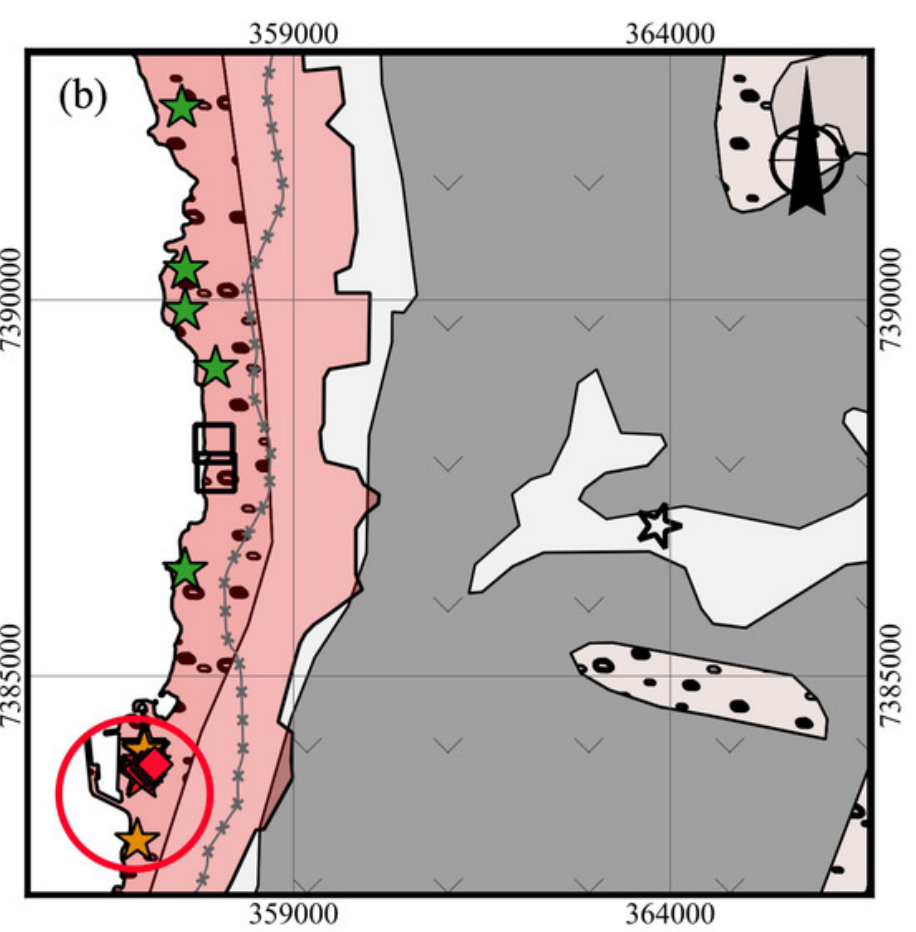




\section{Figure 3}

Box plots of Antofagasta dust

Element concentrations versus distance from the Antofagasta Port (AP). The Box-Whisker plots show the variation in metal concentrations in street dust samples collected at various locations in Antofagasta based on their relative distance from the Port of Antofagasta (nb: In the box-whisker plots, the center vertical line shows the median value, while the length of each box shows the range within which the central $50 \%$ of the values fall, with the box edges showing the first and third quartiles (the interquartile range). Whiskers show values that the range of observed values that fall within $1.5 \times$ the interquartile range. The $y$-axis shows a $\log _{10}$-scale which differs between individual figures). Test statistics reflect results of the Kruskal-Wallis non-parametric ANOVA.
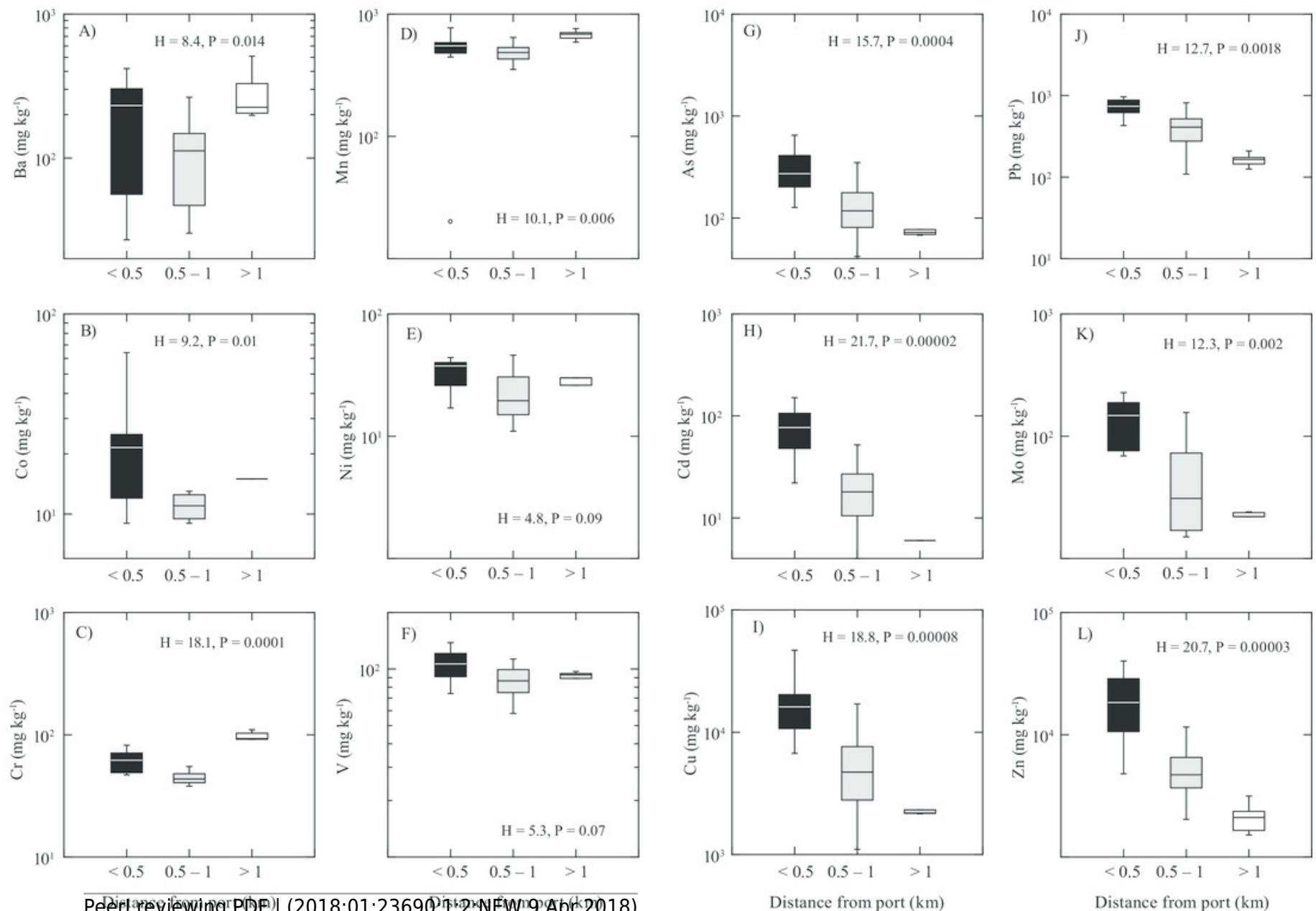


\section{Figure 4}

Principal component analysis of Antofagasta dust

Principal component analysis (PCA) ordination including vectors showing relative correlation strength between principal components (PCs) and concentrations of different metals in street dust collected in Antofagasta. The circles are filled with distinct colors to show their relative proximity to the main gate of the Port of Antofagasta.

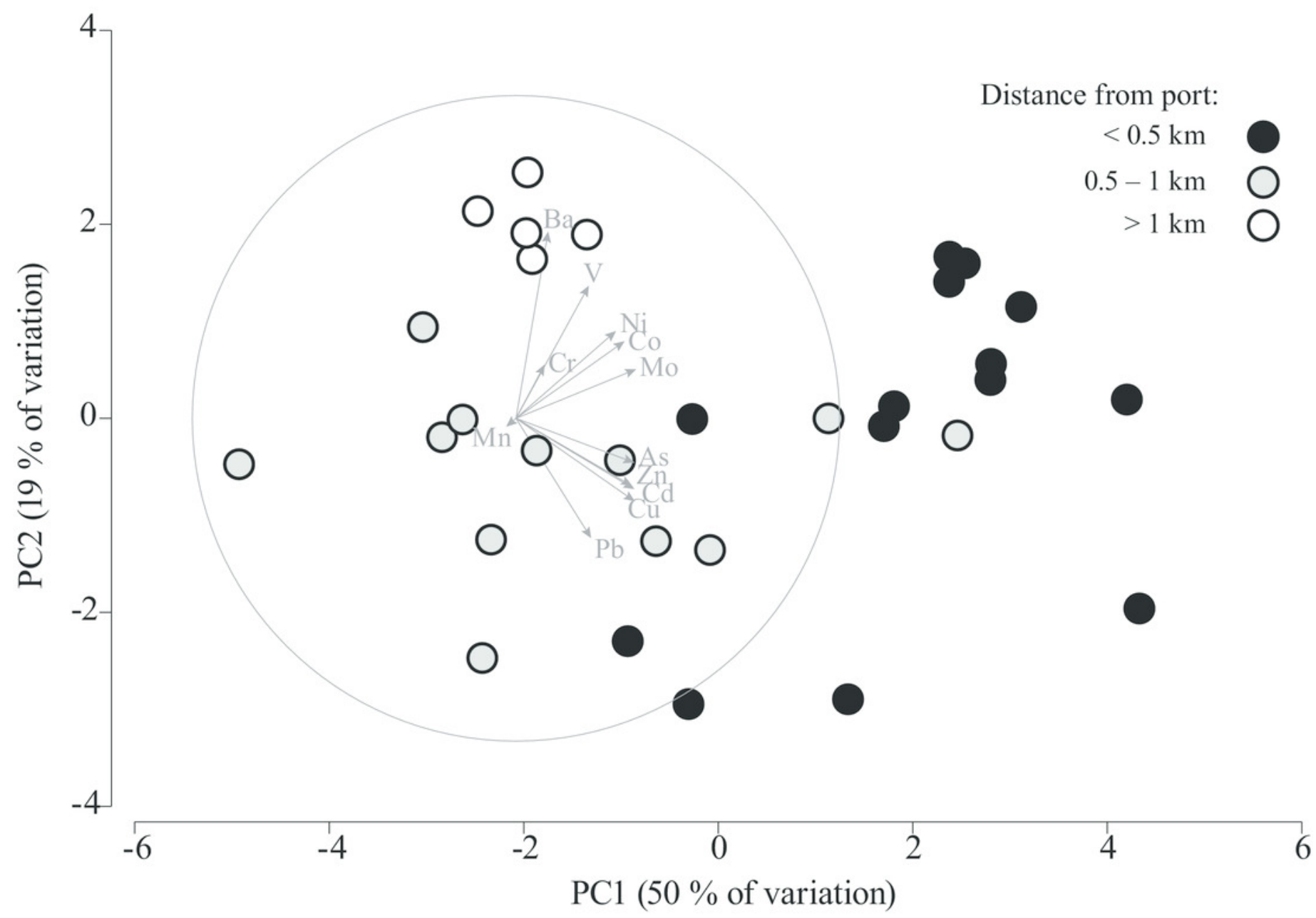




\section{Table $\mathbf{1}$ (on next page)}

Sampling sites

Summary of street dust sampling locations: name of streets, sampling years, sampling institutions, UTM coordinates (WGS-84), and elevations (m. a.s.I.). AP: distance to the Antofagasta Port in kilometers (km). 
1 Table 1. Summary of street dust sampling locations: name of streets, sampling years, sampling 2 institutions, UTM coordinates (WGS-84), and elevations (m.a.s.1.). AP: distance to the Antofagasta Port 3 in kilometers $(\mathrm{km})$.

\begin{tabular}{|c|c|c|c|c|c|c|c|}
\hline Sample & Location & Year & Institution & UTM E & UTM N & $\begin{array}{c}\text { Elevation } \\
\text { (m.a.s.l) }\end{array}$ & $\begin{array}{c}\text { AP } \\
(\mathrm{km})\end{array}$ \\
\hline 1 & Grecia/Salvador Reyes & 2014 & ISP & 356925 & 7382802 & 10 & 0.62 \\
\hline 2 & Grecia/Salvador Reyes & 2014 & ISP & 356925 & 7382802 & 10 & 0.62 \\
\hline 3 & Grecia 1816/21 Mayo & 2014 & ISP & 356973 & 7383725 & 8 & 0.31 \\
\hline 4 & Grecia/21 Mayo & 2014 & ISP & 357075 & 7383834 & 11 & 0.45 \\
\hline 5 & Uribe/Balmaceda Pabellón 1 & 2014 & ISP & 357008 & 7384065 & 9 & 0.65 \\
\hline 6 & Uribe/Balmaceda Pabellón 1 & 2014 & ISP & 357008 & 7384065 & 9 & 0.65 \\
\hline 7 & Uribe/Pabellón 2 & 2014 & ISP & 357025 & 7384049 & 10 & 0.64 \\
\hline 8 & Uribe/Pabellón 2 & 2014 & ISP & 357025 & 7384049 & 10 & 0.64 \\
\hline 9 & Uribe/Pabellón 3 & 2014 & ISP & 357049 & 7384024 & 10 & 0.62 \\
\hline 10 & Uribe/Pabellón 3 & 2014 & ISP & 357049 & 7384024 & 10 & 0.62 \\
\hline 11 & Uribe/Washington Pabellón 4 & 2014 & ISP & 357062 & 7384012 & 10 & 0.61 \\
\hline 12 & Uribe/Washington Pabellón 4 & 2014 & ISP & 357062 & 7384012 & 10 & 0.61 \\
\hline 13 & MOP building in front of the Port & 2014 & ISP & 356969 & 7383667 & 7 & 0.26 \\
\hline 14 & MOP building inside in front of the Port & 2014 & ISP & 356988 & 7383637 & 8 & 0.24 \\
\hline 15 & Liceo Técnico in front of the Port & 2014 & ISP & 357027 & 7383797 & 11 & 0.40 \\
\hline 16 & Colegio Técnico, frontis & 2014 & ISP & 356996 & 7383771 & 10 & 0.37 \\
\hline 17 & Edificio Colectivo Argentina & 2014 & ISP & 357023 & 7383850 & 10 & 0.45 \\
\hline 21 & Edificio Colectivo Perú 1er piso & 2014 & ISP & 357027 & 7383967 & 10 & 0.56 \\
\hline 22 & Edificio Colectivo Perú 2o piso & 2014 & ISP & 357017 & 7384003 & 10 & 0.59 \\
\hline 23 & 14 de Febrero/Edmundo Pérez Zujovic & 2014 & ISP & 357560 & 7386404 & 12 & 3.10 \\
\hline 24 & Av. Edmundo Pérez Zujovic 7344 & 2014 & ISP & 357968 & 7389089 & 14 & 5.77 \\
\hline 25 & Av. Edmundo Pérez Zujovic 8126-9114 & 2014 & ISP & 357562 & 7389860 & 13 & 6.47 \\
\hline 26 & Colegio San Agustín & 2014 & ISP & 357568 & 7390407 & 8 & 7.02 \\
\hline 27 & Condominio Jardines del Norte VI & 2014 & ISP & 357514 & 7392555 & 18 & 9.15 \\
\hline AF-1 & Jardín Infantil Semillita & 2016 & $\mathrm{CM}$ & 357072 & 7383698 & 9 & 0.33 \\
\hline AF-2 & Jardín Infantil Semillita & 2016 & $\mathrm{CM}$ & 357072 & 7383698 & 9 & 0.33 \\
\hline AF-3 & Ex Liceo Técnico A14 & 2016 & $\mathrm{CM}$ & 356986 & 7383759 & 9 & 0.35 \\
\hline AF-4 & Lice Técnico A14 & 2016 & $\mathrm{CM}$ & 357071 & 7383760 & 10 & 0.38 \\
\hline AF-5 & Lice Técnico A14 & 2016 & $\mathrm{CM}$ & 357071 & 7383790 & 11 & 0.41 \\
\hline AF-6 & Liceo Marta Narea A1 & 2016 & $\mathrm{CM}$ & 357128 & 7383791 & 12 & 0.44 \\
\hline $\mathrm{AF}-7$ & Liceo Marta Narea A1 & 2016 & $\mathrm{CM}$ & 357156 & 7383822 & 12 & 0.48 \\
\hline
\end{tabular}




\section{Table 2 (on next page)}

Summary of analytical methodologies utilized in previous studies

Summary of analytical methodologies utilized in previous studies. Antofagasta dust: ISP (2014) and Tchernitchin \& Bolados (2016); rocks: Lucassen \& Franz (1994), Oliveros et al. (1997), and Rogers \& Hawkesworth (1989); soil and sediments: CENMA (2014) and De Gregori et al. (2003). N/A: information not provided. 
1 Table 2. Summary of analytical methodologies utilized in previous studies. Antofagasta dust: ISP (2014) and Tchernitchin \& Bolados (2016); 2 rocks: Lucassen \& Franz (1994), Oliveros et al. (1997), and Rogers \& Hawkesworth (1989); soil and sediments: CENMA (2014) and De Gregori 3 et al. (2003). N/A: information not provided.

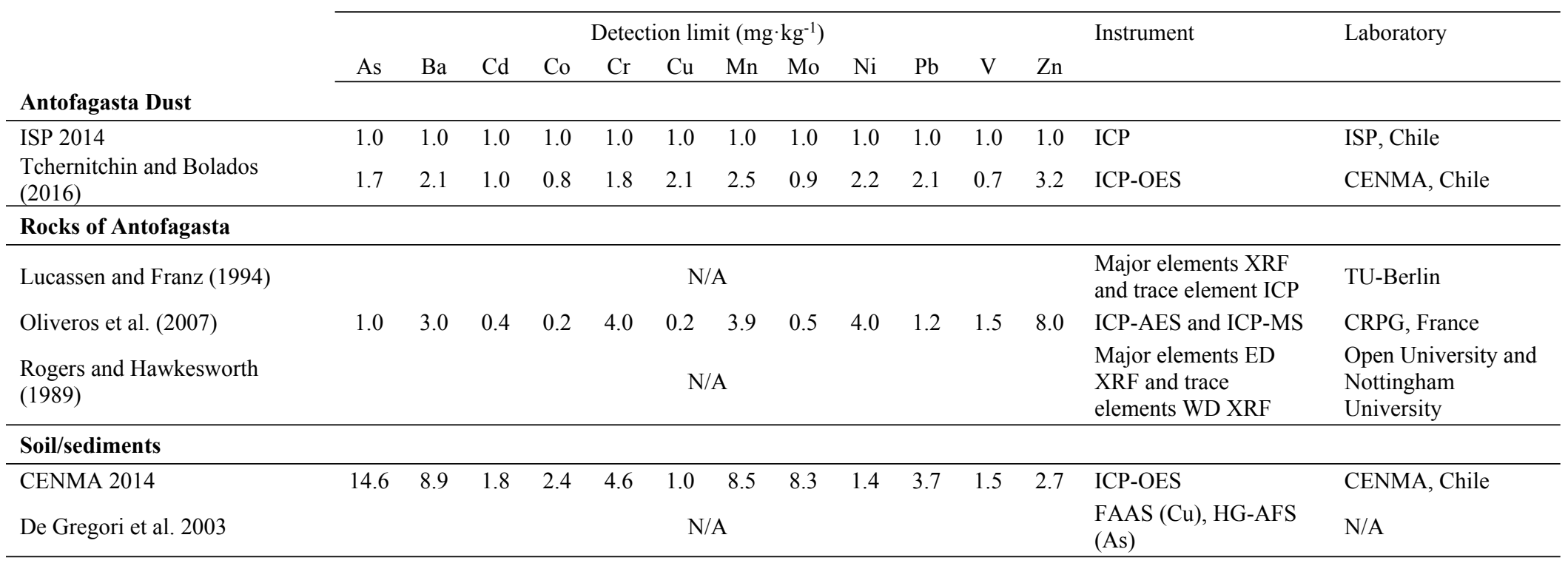




\section{Table 3(on next page)}

Basic statistical summary of Antofagasta dust

Basic statistical summary. Number of data $(n)$, mean, standard deviation $(\sigma)$, relative $\sigma(\sigma \div$ mean $\times 100$ ), median, range, lower and upper $95 \%$ confidence interval. All values are in $\mathrm{mg} \cdot \mathrm{kg}^{-1}$. AP: Antofagasta port; Antofagasta dust data from CM (Tchernitchin and Bolados, 2016) and ISP (ISP, 2014); UCC: upper continental crust values (Rudnick and Gao, 2003). 
1 Table 3. Basic statistical summary. Number of data (n), mean, standard deviation $(\sigma)$, variability ( $\sigma /$ average $\cdot 100)$, median, range, lower and upper $295 \%$ confidence interval. All values are in $\mathrm{mg} \cdot \mathrm{kg}^{-1}$. AP: Antofagasta port; Antofagasta dust data from CM (2016) and ISP (2014); UCC: upper 3 continental crust values (Rudnick and Gao, 2003).

\begin{tabular}{|c|c|c|c|c|c|c|c|c|c|c|c|c|c|c|}
\hline \multirow[b]{2}{*}{ As } & \multirow{2}{*}{$\begin{array}{l}\text { Distance to } \\
\text { AP } \\
\mathrm{km} \\
<0.5\end{array}$} & \multirow{2}{*}{$\begin{array}{c}\mathrm{n} \\
14\end{array}$} & \multirow{2}{*}{$\begin{array}{c}\begin{array}{c}\text { Mean } \\
\left(\mathrm{mg} \cdot \mathrm{kg}^{-1}\right)\end{array} \\
376\end{array}$} & \multirow{2}{*}{$\frac{\begin{array}{c}\sigma \\
\left(\mathrm{mg} \cdot \mathrm{kg}^{-1}\right)\end{array}}{347}$} & \multirow{2}{*}{$\begin{array}{c}\begin{array}{c}\text { Relative } \sigma \\
\%\end{array} \\
92\end{array}$} & \multirow{2}{*}{$\frac{\begin{array}{c}\text { Median } \\
\left(\mathrm{mg} \cdot \mathrm{kg}^{-1}\right)\end{array}}{272}$} & \multicolumn{2}{|c|}{$\begin{array}{c}\text { Range } \\
\left(\mathrm{mg} \cdot \mathrm{kg}^{-1}\right)\end{array}$} & \multicolumn{2}{|c|}{$\begin{array}{c}95 \% \text { confidence } \\
\text { limits } \\
\left(\mathrm{mg} \cdot \mathrm{kg}^{-1}\right) \\
\end{array}$} & \multirow{2}{*}{$\begin{array}{c}\begin{array}{c}\text { Correlation } \\
\text { to distance } \\
\text { to AP }\end{array} \\
-0.46\end{array}$} & \multirow{2}{*}{$\frac{\begin{array}{c}2016-2014 \\
\left(\mathrm{mg} \cdot \mathrm{kg}^{-1}\right)\end{array}}{-186}$} & \multirow{2}{*}{$\begin{array}{c}\begin{array}{c}\mathrm{UCC} \\
\left(\mathrm{mg} \cdot \mathrm{kg}^{-1}\right)\end{array} \\
4.8\end{array}$} & \multirow{2}{*}{$\begin{array}{c}\begin{array}{c}\text { Element } \\
\text { /UCC }\end{array} \\
78\end{array}$} \\
\hline & & & & & & & 127 & 1492 & 175 & 577 & & & & \\
\hline & $0.5-1$ & 12 & 148 & 99 & 67 & 117 & 42 & 350 & 81 & 194 & -0.63 & - & & 31 \\
\hline & $>1$ & 5 & 77 & 14 & 18 & 72 & 68 & 101 & 40 & 94 & 0.18 & - & & 16 \\
\hline & $<0.5$ to $>1$ & 31 & 239 & 269 & 112 & 175 & 42 & 1492 & 141 & 338 & -0.28 & - & & 50 \\
\hline \multirow[t]{4}{*}{$\mathrm{Ba}$} & $<0.5$ & 14 & 216 & 136 & 63 & 234 & 27 & 418 & 137 & 294 & 0.33 & 207 & 624 & 0.3 \\
\hline & $0.5-1$ & 12 & 112 & 71 & 63 & 113 & 30 & 264 & 67 & 157 & -0.71 & - & & 0.2 \\
\hline & $>1$ & 5 & 293 & 132 & 45 & 225 & 198 & 510 & 129 & 457 & 0.50 & - & & 0.5 \\
\hline & $<0.5$ to $>1$ & 31 & 188 & 129 & 69 & 181 & 27 & 510 & 141 & 236 & 0.39 & - & & 0.3 \\
\hline \multirow[t]{4}{*}{$\mathrm{Cd}$} & $<0.5$ & 14 & 81 & 37 & 46 & 77 & 22 & 151 & 59 & 102 & -0.25 & 35 & 0.09 & 895 \\
\hline & $0.5-1$ & 12 & 20 & 13 & 68 & 18 & 4 & 52 & 11 & 28 & -0.48 & - & & 221 \\
\hline & $>1$ & 5 & 6 & 1 & 17 & 6 & 4 & 7 & 4 & 7 & -0.56 & - & & 63 \\
\hline & $<0.5$ to $>1$ & 31 & 45 & 42 & 93 & 28 & 4 & 151 & 30 & 60 & -0.43 & - & & 500 \\
\hline \multirow[t]{4}{*}{ Co } & $<0.5$ & 14 & 22 & 14 & 61 & 21 & 9 & 64 & 15 & 30 & 0.00 & 16 & 17.3 & 1.3 \\
\hline & $0.5-1$ & 12 & 12 & 4 & 34 & 11 & 6 & 20 & 9 & 14 & 0.01 & - & & 0.7 \\
\hline & $>1$ & 5 & 15 & 1 & 8 & 15 & 13 & 15 & 13 & 16 & -0.76 & - & & 0.8 \\
\hline & $<0.5$ to $>1$ & 31 & 17 & 11 & 62 & 15 & 6 & 64 & 13 & 21 & -0.13 & - & & 1.0 \\
\hline \multirow[t]{4}{*}{$\mathrm{Cr}$} & $<0.5$ & 14 & 62 & 12 & 19 & 62 & 47 & 82 & 55 & 69 & -0.68 & -2 & 92 & 0.7 \\
\hline & $0.5-1$ & 12 & 46 & 12 & 25 & 43 & 28 & 76 & 38 & 53 & -0.04 & - & & 0.5 \\
\hline & $>1$ & 5 & 94 & 15 & 16 & 93 & 71 & 110 & 76 & 112 & -0.95 & - & & 1.0 \\
\hline & $<0.5$ to $>1$ & 31 & 61 & 20 & 33 & 55 & 28 & 110 & 53 & 68 & 0.57 & & & 0.7 \\
\hline \multirow[t]{3}{*}{$\mathrm{Cu}$} & $<0.5$ & 14 & 17914 & 9897 & 55 & 16114 & 6725 & $\begin{array}{c}4689 \\
8 \\
1704\end{array}$ & 12199 & 23628 & -0.62 & -3044 & 28 & 640 \\
\hline & $0.5-1$ & 12 & 6103 & 5059 & 83 & 4735 & 1103 & 7 & 2889 & 9317 & -0.61 & - & & 218 \\
\hline & $>1$ & 5 & 2287 & 187 & 8 & 2188 & 2153 & 2601 & 2054 & 2519 & -0.06 & - & & 82 \\
\hline
\end{tabular}




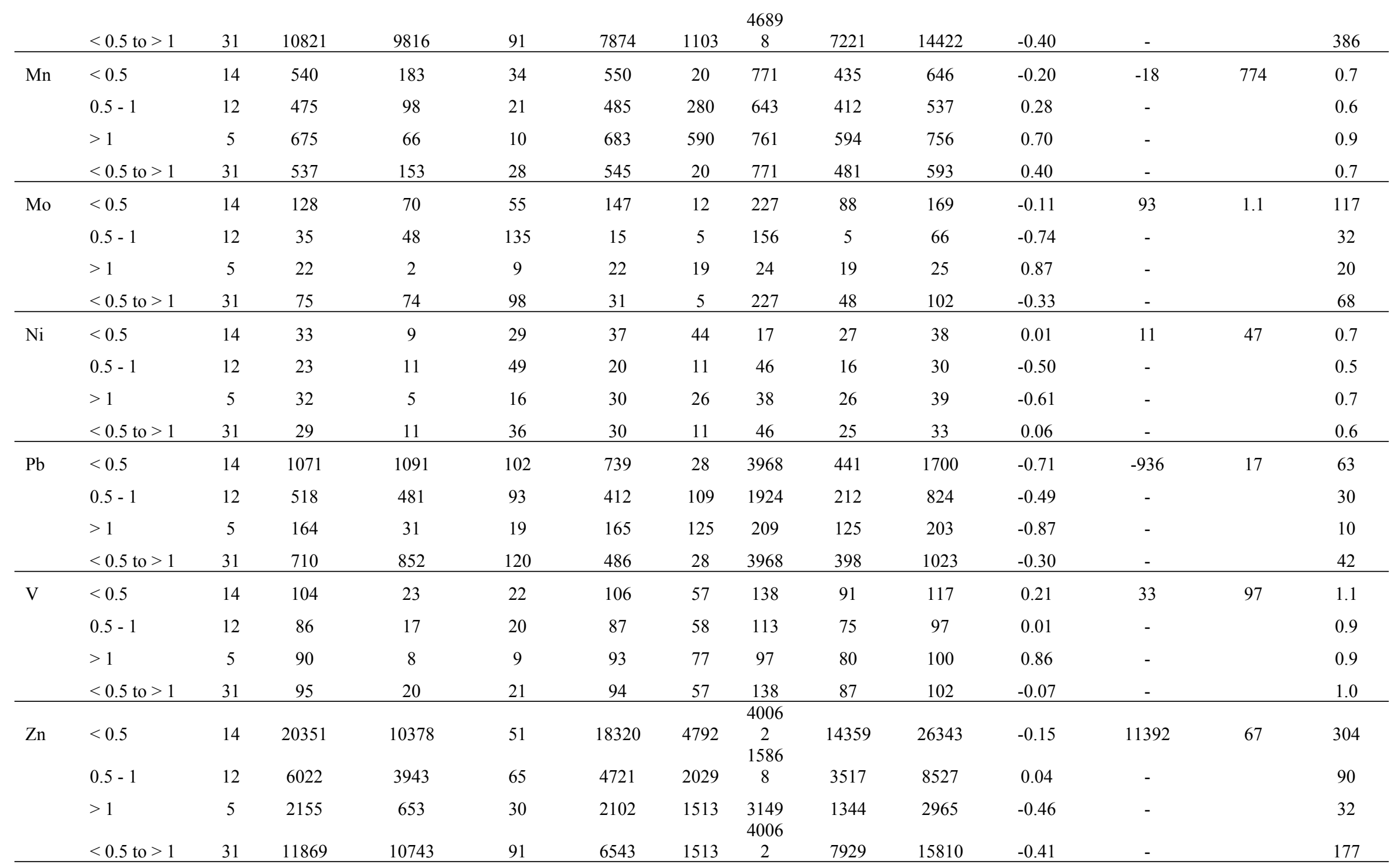




\section{Table 4 (on next page)}

Geo-accumulation index of Antofagasta dust

Geo-accumulation index (Muller, 1979). $\mathrm{I}_{\text {geo }} \leq 0$ non-contaminated; $0<\mathrm{I}_{\text {geo }} \leq 1$ non- to slightly contaminated; $1<\mathrm{I}_{\text {geo }} \leq 2$ moderately contaminated; $2<\mathrm{I}_{\text {geo }} \leq 3$ moderately to highly contaminated; $3<\mathrm{I}_{\text {geo }} \leq 4$ highly contaminated; $4<\mathrm{I}_{\text {geo }} \leq 5$ highly to extremely contaminated; I geo $>5$ extremely contaminated. Note: below the sample type, distances are given from the Antofagasta Port. 
Table 4. Geo-accumulation index (Muller, 1979). $\mathrm{I}_{\text {geo }} \leq 0$ non-contaminated; $0<\mathrm{I}_{\text {geo }} \leq 1$ non- to slightly contaminated; $1<\mathrm{I}_{\text {geo }} \leq 2$ moderately contaminated; $2<\mathrm{I}_{\text {geo }} \leq 3$ moderately to highly contaminated; $3<\mathrm{I}_{\text {geo }} \leq 4$ highly contaminated; $4<\mathrm{I}_{\text {geo }} \leq 5$ highly to extremely contaminated; $3 \mathrm{I}_{\text {geo }}>5$ extremely contaminated. Note: below the sample type, distances are given from the Antofagasta Port.

\begin{tabular}{|c|c|c|c|c|c|c|c|c|c|c|c|c|c|c|c|}
\hline & \multicolumn{3}{|c|}{ Soil } & \multicolumn{3}{|c|}{ Metamorphic rocks } & \multicolumn{3}{|c|}{ Volcanic rocks } & \multicolumn{3}{|c|}{ Intrusive rocks } & \multicolumn{3}{|c|}{ Igneous dikes } \\
\hline & $<0.5 \mathrm{~km}$ & $\begin{array}{c}0.5-1 \\
\mathrm{~km}\end{array}$ & $\begin{array}{l}>1 \\
\mathrm{~km}\end{array}$ & $<0.5 \mathrm{~km}$ & $\begin{array}{c}0.5-1 \\
\mathrm{~km}\end{array}$ & $\begin{array}{l}>1 \\
\mathrm{~km}\end{array}$ & $<0.5 \mathrm{~km}$ & $\begin{array}{c}0.5-1 \\
\mathrm{~km}\end{array}$ & $\begin{array}{l}>1 \\
\mathrm{~km}\end{array}$ & $<0.5 \mathrm{~km}$ & $\begin{array}{c}0.5-1 \\
\mathrm{~km}\end{array}$ & $\begin{array}{l}>1 \\
\mathrm{~km}\end{array}$ & $<0.5 \mathrm{~km}$ & $\begin{array}{c}0.5-1 \\
\mathrm{~km}\end{array}$ & $\begin{array}{l}>1 \\
\mathrm{~km}\end{array}$ \\
\hline As & 4 & 3 & 2 & - & - & - & 5 & 4 & 3 & 7 & 6 & 5 & - & - & - \\
\hline $\mathrm{Ba}$ & - & - & - & 0 & -1 & 0 & -1 & -2 & -1 & -1 & -2 & 0 & -1 & -2 & 0 \\
\hline $\mathrm{Cd}$ & 5 & 3 & 1 & - & - & - & - & - & - & - & - & - & - & - & - \\
\hline $\mathrm{Co}$ & & & & & & & -1 & -2 & -1 & -1 & -2 & -1 & - & - & - \\
\hline $\mathrm{Cr}$ & 1 & 0 & 1 & 0 & -1 & 0 & 0 & -1 & 0 & -1 & -2 & -1 & -1 & -2 & -1 \\
\hline $\mathrm{Cu}$ & 6 & 5 & 4 & 7 & 6 & 4 & 7 & 6 & 4 & 7 & 6 & 4 & 6 & 5 & 4 \\
\hline $\mathrm{Mn}$ & - & - & - & -2 & -2 & -1 & -2 & -2 & -2 & -1 & -2 & -1 & -1 & -1 & -1 \\
\hline Mo & - & - & - & - & - & - & 6 & 4 & 3 & 5 & 4 & 3 & - & - & - \\
\hline $\mathrm{Ni}$ & 0 & 0 & 0 & 0 & -1 & 0 & 0 & -1 & 0 & 0 & -1 & 0 & 0 & -1 & 0 \\
\hline $\mathrm{Pb}$ & 6 & 5 & 3 & - & - & - & 6 & 5 & 4 & 8 & 7 & 5 & - & - & - \\
\hline V & - & - & - & -2 & -2 & -2 & -2 & -2 & -2 & -2 & -2 & -2 & -2 & -2 & -2 \\
\hline $\mathrm{Zn}$ & 7 & 5 & 4 & 7 & 6 & 4 & 6 & 4 & 3 & 8 & 6 & 5 & 8 & 6 & 5 \\
\hline
\end{tabular}




\section{Table 5 (on next page)}

Enrichment Factors obtained in Antofagasta dust

Enrichment Factors obtained in Antofagasta from volcanic, intrusive, and metamorphic rocks as well as from dikes and soils. Values close to 1 indicate that the material originates from the same parent material (Zoller et al., 1974). High values signify that they do not originate from that parent material. Note: below the sample type, distances are given from the Antofagasta Port. 
Table 5. Enrichment Factors obtained in Antofagasta from volcanic, intrusive, and metamorphic rocks as well as from dikes and soils. Values 2 close to 1 indicate that the material originates from the same parent material (Zoller et al., 1974). High values signify that they do not originate 3 from that parent material. Note: below the sample type, distances are given from the Antofagasta Port.

\begin{tabular}{|c|c|c|c|c|c|c|c|c|c|c|c|c|c|c|c|}
\hline & \multicolumn{3}{|c|}{ Soil } & \multicolumn{3}{|c|}{ Metamorphic rocks } & \multicolumn{3}{|c|}{ Volcanic rocks } & \multicolumn{3}{|c|}{ Intrusive rocks } & \multicolumn{3}{|c|}{ Igneous dikes } \\
\hline & $\begin{array}{c}<0.5 \\
\mathrm{~km} \\
\end{array}$ & $\begin{array}{c}0.5-1 \\
\mathrm{~km}\end{array}$ & $\begin{array}{l}>1 \\
\mathrm{~km}\end{array}$ & $\begin{array}{c}<0.5 \\
\mathrm{~km} \\
\end{array}$ & $\begin{array}{c}0.5-1 \\
\mathrm{~km}\end{array}$ & $\begin{array}{l}>1 \\
\mathrm{~km}\end{array}$ & $\begin{array}{c}<0.5 \\
\mathrm{~km} \\
\end{array}$ & $\begin{array}{c}0.5-1 \\
\mathrm{~km}\end{array}$ & $\begin{array}{l}>1 \\
\mathrm{~km}\end{array}$ & $\begin{array}{c}<0.5 \\
\mathrm{~km}\end{array}$ & $\begin{array}{c}0.5-1 \\
\mathrm{~km}\end{array}$ & $\begin{array}{l}>1 \\
\mathrm{~km}\end{array}$ & $\begin{array}{c}<0.5 \\
\mathrm{~km} \\
\end{array}$ & $\begin{array}{c}0.5-1 \\
\mathrm{~km}\end{array}$ & $\begin{array}{l}>1 \\
\mathrm{~km}\end{array}$ \\
\hline As & 7 & 4 & 2 & - & - & - & 91 & 50 & 22 & 235 & 130 & 55 & - & - & - \\
\hline $\mathrm{Ba}$ & - & - & - & 2 & 1 & 3 & 1 & 1 & 2 & 1 & 1 & 2 & 3 & 2 & 4 \\
\hline $\mathrm{Cd}$ & 20 & 7 & 2 & - & - & - & - & - & - & - & - & - & - & - & - \\
\hline $\mathrm{Co}$ & - & - & - & - & - & - & 1 & 1 & 1 & 1 & 1 & 1 & - & - & - \\
\hline $\mathrm{Cr}$ & 1 & 1 & 1 & 2 & 2 & 3 & 2 & 2 & 3 & 1 & 1 & 1 & 2 & 2 & 3 \\
\hline $\mathrm{Cu}$ & 45 & 21 & 7 & 313 & 150 & 46 & 340 & 163 & 50 & 236 & 113 & 35 & 364 & 174 & 53 \\
\hline $\mathrm{Mn}$ & - & - & - & 1 & 1 & 1 & 1 & 1 & 1 & 1 & 1 & 1 & 2 & 2 & 2 \\
\hline Mo & - & - & - & - & - & - & 135 & 52 & 26 & 70 & 27 & 14 & & & \\
\hline $\mathrm{Ni}$ & 1 & 1 & 1 & 2 & 2 & 2 & 2 & 2 & 2 & 2 & 2 & 2 & 4 & 4 & 4 \\
\hline $\mathrm{Pb}$ & 35 & 24 & 6 & - & - & - & 196 & 133 & 34 & 365 & 248 & 64 & - & - & - \\
\hline $\mathrm{V}$ & - & - & - & 1 & 1 & 1 & 1 & 1 & 1 & 1 & 1 & 1 & 1 & 2 & 1 \\
\hline $\mathrm{Zn}$ & 74 & 31 & 9 & 365 & 151 & 44 & 172 & 71 & 21 & 476 & 198 & 58 & 934 & 388 & 113 \\
\hline
\end{tabular}




\section{Table 6(on next page)}

Chemical daily intake and Hazard Index of Antofagasta dust

Chemical daily intake and Hazard Index. (A) CDI: chemical daily intake (ingestion); (B) HI:

hazard index (ingestion); values above 1 indicate health issue risks (Luo et al., 2012). RfD: reference dose (references of $R f D$ values are in the text). 
1 Table 6. Chemical daily intake and Hazard Index. (a) CDI: chemical daily intake (ingestion); (b) $H I$ :

2 hazard index; values above 1 indicate health issue risks (Luo et al., 2012). RfD: reference dose (references

3 of $R f D$ values are in the text).

(a)

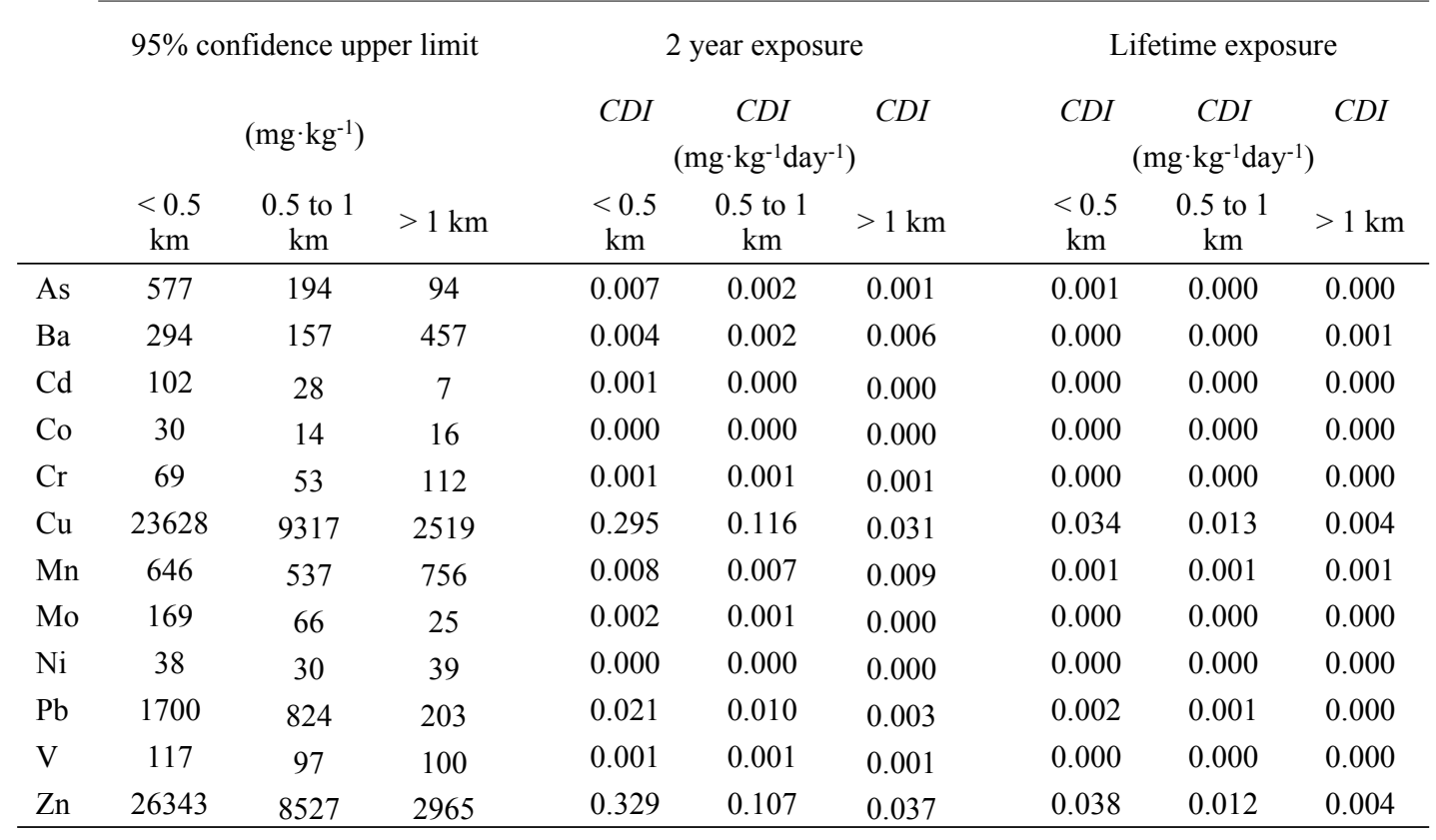

(b)

\begin{tabular}{|c|c|c|c|c|c|c|c|c|}
\hline & & \multirow{3}{*}{$\begin{array}{c}R f D \\
\left(\mathrm{mg} \cdot \mathrm{kg}^{-1} \mathrm{day}^{-1}\right)\end{array}$} & \multicolumn{3}{|c|}{2 year exposure } & \multicolumn{3}{|c|}{ Lifetime exposure } \\
\hline & & & $H I$ & $H I$ & $H I$ & $H I$ & $H I$ & $H I$ \\
\hline & & & $\begin{array}{c}<0.5 \\
\mathrm{~km}\end{array}$ & $\begin{array}{c}0.5 \text { to } 1 \\
\mathrm{~km}\end{array}$ & $>1 \mathrm{~km}$ & $\begin{array}{c}<0.5 \\
\mathrm{~km}\end{array}$ & $\begin{array}{c}0.5 \text { to } 1 \\
\mathrm{~km}\end{array}$ & $>1 \mathrm{~km}$ \\
\hline As & $R f D$ & 0.0003 & 24 & 9 & 4 & 3 & 1 & 0 \\
\hline $\mathrm{Ba}$ & $R f D$ & 0.0700 & 0 & 0 & 0 & 0 & 0 & 0 \\
\hline $\mathrm{Cd}$ & $R f D$ & 0.0010 & 1 & 1 & 0 & 0 & 0 & 0 \\
\hline $\mathrm{Co}$ & $R f D$ & 0.0300 & 0 & 0 & 0 & 0 & 0 & 0 \\
\hline $\mathrm{Cr}$ & $\begin{array}{l}R f D \\
{[\mathrm{Cr}(\mathrm{VI})]}\end{array}$ & 0.0030 & 0 & 0 & 0 & 0 & 0 & 0 \\
\hline $\mathrm{Cu}$ & $M R L$ & 0.0100 & 30 & 12 & 3 & 3 & 1 & 0 \\
\hline $\mathrm{Mn}$ & $R f D$ & 0.1400 & 0 & 0 & 0 & 0 & 0 & 0 \\
\hline Mo & $R f D$ & 0.0050 & 0 & 0 & 0 & 0 & 0 & 0 \\
\hline $\mathrm{Ni}$ & $R f D$ & 0.0200 & 0 & 0 & 0 & 0 & 0 & 0 \\
\hline $\mathrm{Pb}$ & - & - & - & - & - & - & - & - \\
\hline $\mathrm{V}$ & $R f D$ & 0.0070 & 0 & 0 & 0 & 0 & 0 & 0 \\
\hline $\mathrm{Zn}$ & $R f D$ & 0.3000 & 1 & 0 & 0 & 0 & 0 & 0 \\
\hline
\end{tabular}


Table 7 (on next page)

Bioaccessibility of Antofagasta dust

Bioaccessibility assay of three dust samples located in close proximity to the Antofagasta Port. 
1 Table 7. Bioaccessibility assay of three dust samples located in close proximity to the Antofagasta Port.

\begin{tabular}{|c|c|c|c|c|c|c|c|c|}
\hline & & $\begin{array}{l}\text { AFA-237 } \\
\text { Port Gate }\end{array}$ & $\begin{array}{l}\text { AFA-238 } \\
\text { Window in } \\
\text { front of the } \\
\text { galpón }\end{array}$ & $\begin{array}{l}\text { AFA-239 } \\
\text { Building }\end{array}$ & \multirow{3}{*}{$\begin{array}{c}\text { Mean } \\
\text { bioaccessibility } \\
(\%)\end{array}$} & \multirow{3}{*}{$\begin{array}{l}\text { Detection } \\
\text { limit } \\
\left(\mathrm{mg} \cdot \mathrm{kg}^{-1}\right)\end{array}$} & \multirow[t]{3}{*}{$\begin{array}{c}\text { Quantification } \\
\text { limit } \\
\left(\mathrm{mg} \cdot \mathrm{kg}^{-1}\right)\end{array}$} & \multirow[t]{3}{*}{$\begin{array}{c}\text { Reference } \\
\text { material } \\
\text { recovery }(\%)\end{array}$} \\
\hline & UTM E & 356907 & 356899 & 357208 & & & & \\
\hline \multirow[t]{3}{*}{ Coordinates } & UTM N & 7383395 & 7383305 & 7384279 & & & & \\
\hline & total $\left(\mathrm{mg} \cdot \mathrm{kg}^{-1}\right)$ & 243 & 92 & 85 & & & & \\
\hline & bioaccessible $\left(\mathrm{mg} \cdot \mathrm{kg}^{-1}\right)$ & 27 & 58 & 65 & & & & \\
\hline \multirow[t]{3}{*}{ As } & $\%$ of bioaccessibility & 11 & 63 & 76 & 50 & 1.7 & 5.5 & 81.6 \\
\hline & total $\left(\mathrm{mg} \cdot \mathrm{kg}^{-1}\right)$ & 62 & 34 & 17 & & & & \\
\hline & bioaccessible $\left(\mathrm{mg} \cdot \mathrm{kg}^{-1}\right)$ & 2 & 2 & 3 & & & & \\
\hline \multirow[t]{3}{*}{$\mathrm{Cd}$} & $\%$ of bioaccessibility & 3 & 6 & 21 & 10 & 1.0 & 3.4 & 83.2 \\
\hline & total $\left(\mathrm{mg} \cdot \mathrm{kg}^{-1}\right)$ & 15246 & 4157 & 3737 & & & & \\
\hline & bioaccessible $\left(\mathrm{mg} \cdot \mathrm{kg}^{-1}\right)$ & 78 & 1024 & 1342 & & & & \\
\hline \multirow[t]{3}{*}{$\mathrm{Cu}$} & $\%$ of bioaccessibility & 1 & 25 & 36 & 20 & 2.1 & 6.9 & 95.4 \\
\hline & total $\left(\mathrm{mg} \cdot \mathrm{kg}^{-1}\right)$ & 197 & 31 & 14 & & & & \\
\hline & bioaccessible $\left(\mathrm{mg} \cdot \mathrm{kg}^{-1}\right)$ & 0 & 0 & 0 & & & & \\
\hline \multirow[t]{3}{*}{ Mo } & $\%$ of bioaccessibility & 0 & 0 & 0 & 0 & 0.9 & 3.0 & 87.8 \\
\hline & total $\left(\mathrm{mg} \cdot \mathrm{kg}^{-1}\right)$ & 666 & 371 & 335 & & & & \\
\hline & bioaccessible $\left(\mathrm{mg} \cdot \mathrm{kg}^{-1}\right)$ & 4 & 127 & 146 & & & & \\
\hline \multirow[t]{3}{*}{$\mathrm{Pb}$} & $\%$ of bioaccessibility & 1 & 34 & 44 & 26 & 2.1 & 7.0 & 89.4 \\
\hline & total $\left(\mathrm{mg} \cdot \mathrm{kg}^{-1}\right)$ & 19692 & 8821 & 3021 & & & & \\
\hline & bioaccessible $\left(\mathrm{mg} \cdot \mathrm{kg}^{-1}\right)$ & 49 & 941 & 1135 & & & & \\
\hline $\mathrm{Zn}$ & $\%$ of bioaccessibility & 0 & 11 & 38 & 16 & 3.2 & 10.6 & 98.1 \\
\hline
\end{tabular}




\section{Table 8 (on next page)}

City dust from Antofagasta

City dust from Antofagasta (ISP, 2014; Tchernitchin and Bolados, 2016) and Santiago (Tapia et al., 2009), Chile; Fushun (Kong et al., 2011), Baoji (Lu et al., 2009), Zhuzhou (Li et al., 2013), and the Qingshan district (QS) in Wuhan (Zhu et al., 2013), China; and the Islamabad Expressway in Pakistan (Faiz et al., 2009). 
1 Table 8. City dust from Antofagasta (ISP, 2014; Tchernitchin \& Bolados, 2016) and Santiago (Tapia et al., 2009), Chile; Fushun (Kong et al., 2 2011), Baoji (Lu et al., 2009), Zhuzhou (Li et al., 2013), and the Qingshan district (QS) in Wuhan (Zhu et al., 2013), China; and the Islamabad 3 Expressway in Pakistan (Faiz et al., 2009).

\begin{tabular}{|c|c|c|c|c|c|c|c|}
\hline & \multicolumn{2}{|c|}{ Chile } & \multicolumn{4}{|c|}{ China } & \multirow{2}{*}{$\begin{array}{l}\text { Pakistan } \\
\text { Islamabad } \\
\left(\mathrm{mg} \cdot \mathrm{kg}^{-1}\right) \\
\end{array}$} \\
\hline & $\begin{array}{c}\text { Antofagasta } \\
\left(\mathrm{mg} \cdot \mathrm{kg}^{-1}\right)\end{array}$ & $\begin{array}{l}\text { Santiago } \\
\left(\mathrm{mg} \cdot \mathrm{kg}^{-1}\right)\end{array}$ & $\begin{array}{c}\text { Fushun } \\
\left(\mathrm{mg} \cdot \mathrm{kg}^{-1}\right)\end{array}$ & $\begin{array}{c}\text { Baoji } \\
\left(\mathrm{mg} \cdot \mathrm{kg}^{-1}\right) \\
\end{array}$ & $\begin{array}{l}\text { Zhuzhou } \\
\left(\mathrm{mg} \cdot \mathrm{kg}^{-1}\right)\end{array}$ & $\begin{array}{c}\text { QS } \\
\left(\mathrm{mg} \cdot \mathrm{kg}^{-1}\right)\end{array}$ & \\
\hline As & $239 \pm 269$ & $12 \pm 1.9$ & - & - & $89 \pm 183$ & $32 \pm 20$ & - \\
\hline $\mathrm{Ba}$ & $188 \pm 129$ & $411 \pm 124$ & - & - & - & $1,610 \pm 984$ & - \\
\hline $\mathrm{Cd}$ & $45 \pm 42$ & $0.8 \pm 0.19$ & - & - & $41 \pm 117$ & $2.8 \pm 1.8$ & $5.0 \pm 1.0$ \\
\hline Co & $17 \pm 11$ & $11 \pm 2.3$ & $139 \pm 179$ & - & $13 \pm 11$ & $20 \pm 12$ & - \\
\hline $\mathrm{Cr}$ & $61 \pm 20$ & $38 \pm 11$ & $5,334 \pm 10,667$ & - & $125 \pm 54$ & $172 \pm 96$ & - \\
\hline $\mathrm{Cu}$ & $10,821 \pm 9,816$ & $669 \pm 567$ & $149 \pm 177$ & $123 \pm 43$ & $139 \pm 148$ & $213 \pm 180$ & $52 \pm 18$ \\
\hline $\mathrm{Mn}$ & $573 \pm 153$ & $619 \pm 109$ & - & - & - & - & - \\
\hline Mo & $75 \pm 74$ & $73 \pm 27$ & - & - & $6.4 \pm 12.4$ & $7.2 \pm 3.9$ & - \\
\hline $\mathrm{Ni}$ & $29 \pm 11$ & $24 \pm 6.4$ & $302 \pm 555$ & $49 \pm 30$ & $40 \pm 16$ & $38 \pm 14$ & $23 \pm 6$ \\
\hline $\mathrm{Pb}$ & $710 \pm 852$ & $127 \pm 50$ & - & $408 \pm 296$ & $956 \pm 2,815$ & $336 \pm 191$ & $104 \pm 29$ \\
\hline V & $95 \pm 20$ & $54 \pm 11$ & $14.6 \pm 4.1$ & - & - & - & - \\
\hline $\mathrm{Zn}$ & $11,869 \pm 10,743$ & $943 \pm 411$ & - & $715 \pm 320$ & $2,379 \pm 5,145$ & $1,250 \pm 889$ & $116 \pm 35$ \\
\hline
\end{tabular}

4 